\title{
GSEs, Mortgage Rates, and the Long-Run Effects of Mortgage Securitization ${ }^{1}$
}

\author{
Wayne Passmore \\ Board of Governors \\ Federal Reserve System \\ Roger Sparks \\ Mills College \\ Jamie Ingpen \\ Board of Governors \\ Federal Reserve System
}

December, 2001

\footnotetext{
${ }^{1}$ We would like to thank Eric Engen, Kathleen Johnson, Andreas Lehnert, Dean Maki, and Steve Oliner for their useful comments. Also, we would like to thank Gillian Burgess for her excellent research assistance. We take responsibility for all errors. The analysis and conclusions set forth are those of the authors and do not indicate concurrence by other members of the research staff, by the Board of Governors, or by the Federal Reserve Banks. Please send correspondence to Wayne Passmore, Assistant Director, Mail Stop 93, Federal Reserve Board, Washington D.C. 20551 or send e-mail to Wayne.Passmore@FRB.GOV.
} 


\title{
GSEs, Mortgage Rates, and the Long-Run Effects of Mortgage Securitization
}

\begin{abstract}
Our paper compares mortgage securitization undertaken by government-sponsored enterprises (GSEs) with that undertaken by private firms, with an emphasis on how each type of mortgage securitization affects mortgage rates. We build a model illustrating that market structure, government sponsorship, and the characteristics of the mortgages securitized are all important determinants of mortgage rates. We find that GSEs generally-but not always-lower mortgage rates, particularly when the GSEs behave competitively, because the GSEs' implicit government backing allows them to sell securities without the credit enhancements needed in the private sector. Using our simulation model, we demonstrate that when mortgages eligible for purchase by the GSEs have characteristics similar to other mortgages, the GSEs' implicit governmentbacking generates differences in mortgage rates similar to those currently observed in the mortgage market (which range between zero and fifty basis points). However, if the mortgages purchased by GSEs are less costly to originate and securitize, and the if the GSEs behave competitively, then the simulated spread in mortgage rates can be much larger than that observed in the data.
\end{abstract}




\section{Introduction}

The mortgage-backed securities market in the United States is dominated by two privately-owned but government-sponsored institutions--the Federal National Mortgage Association (Fannie Mae) and the Federal Home Loan Mortgage Corporation (Freddie Mac) — and includes a variety of smaller, fully private firms that securitize the remaining mortgages, which are not eligible for securitization by Fannie Mae or Freddie Mac. The outstanding stock of mortgages securitized and made available to investors by Fannie Mae and Freddie Mac totaled more than $\$ 1.2$ trillion at the end of 2000, roughly four times the amount securitized by the fully private part of the market. ${ }^{2}$

Investors generally perceive Fannie Mae and Freddie Mac as having the implicit backing of the U.S. government, which allows these government-sponsored enterprises (GSEs) to issue debt at lower interest rates than they could otherwise and to securitize mortgages without providing or purchasing credit enhancements. This implicit subsidy benefits Fannie Mae and Freddie Mac's shareholders, though part of the subsidy may flow through to the primary mortgage market. $^{3}$

At first blush, one might wonder why any of the subsidy would pass through to homeowners, particularly since in competitive markets, if only two producers among many receive a subsidy, then those two subsidized producers simply have increased profits and there is no effect on prices for the product. ${ }^{4}$ Goodman and Passmore (1992) and Hermalin and

${ }^{2}$ Fannie and Freddie also directly held about $\$ 1.0$ trillion of mortgages and mortgage-backed securities at year-end 2000. During the 1990s, their yearly securitization rate is estimated to have fluctuated between 45 percent and 78 percent of conventional conforming mortgage originations. Information about Fannie's and Freddie's holdings is from their quarterly and annual reports, whereas information about the fully private market is from Inside $M B S \& A B S$, February 2, 2000, page 7. The securitization rate is from Inside Mortgage Finance Publications (2000).

${ }^{3}$ For a review of efforts to measure the size of the GSE subsidy, see Feldman (1999). For an exposition of how the GSE subsidy benefits shareholders and others, see Congressional Budget Office $(1996,2001)$ and General Accounting Office (1996).

${ }^{4}$ Note that Fannie and Freddie-like all insurers of credit risk-face an adverse selection problem that requires they include a "lemons premium" in the purchase price they offer for mortgages. Theoretically, their subsidy could be completely absorbed by the GSEs' efforts to avoid adverse selection (Passmore and Sparks, 1996 \& 2000). 
Jaffee (1996) argue that the subsidy may be partly transmitted because the secondary market has many of the conditions required for collusion — two rivals with roughly equal market share and almost infinite production capacity, homogeneity of product, and high entry and exit barriers - and thus these two firms are cognizant of the effects their prices have on demand. ${ }^{5}$ Given these conditions, if Fannie Mae and Freddie Mac compete vigorously with each other (they are "Bertrand competitors"), then most of the GSE subsidy is likely to be passed on to mortgage borrowers. Evidence of a subsidy pass- through comes from three previous studies (Hendershott and Shilling, 1989; ICF, 1990; and Cotterman and Pearce, 1996), which found that interest rates for mortgages eligible for purchase by the GSEs are about 30 basis points less than mortgage rates for other mortgages.

How does the GSEs' implicit subsidy affect mortgage securitization, and under what conditions does it lower mortgage rates? Unlike when GSEs buy and hold mortgages, and thus then fund with implicitly guaranteed debt, when the GSEs issue mortgage-backed securities, they do not fund the mortgages directly. Thus, the implicit subsidy on the GSEs' debt cannot directly affect the yields on the mortgage-backed securities because debt is not used. With securitization, the mortgages are funded by the purchasers of the mortgage-backed securities. However, we find that GSEs generally — but not always — cause mortgage rates to be lower in the long run than they would be with private securitization because the GSEs have implicit public backing. When GSEs securitize mortgages, their implicit government backing allows them to sell securities without holding the capital or purchasing the credit enhancements needed in the private sector.

We use a simulation model to study the conditions under which implicit government backing of mortgage-backed securities lowers mortgage rates, and we compare the simulated spread between GSE and private mortgage rates to empirical spread to infer the underlying market structure. Under the assumption that conforming mortgages (and their associated mortgage-backed securities) are identical to nonconforming mortgages (and their associated mortgage-backed securities), our simulations generally suggest that the observed difference in mortgage rates is greater than the simulated difference when Fannie and Freddie are modeled as

\footnotetext{
${ }^{5}$ Neither study was able to establish definitely that Fannie and Freddie actually collude.
} 
monopolists and similar to the simulated difference when they are modeled as competitors. However, if GSE mortgage-backed securities are more liquid than non-GSE mortgage-backed securities, or if conforming mortgages are less expensive to originate or evaluate than nonconforming mortgages, then our simulations suggest the observed mortgage spread is less than would be realized if Fannie and Freddie behaved competitively. Our results highlight the difficulty in analyzing the causes of the small differences between the GSE and non-GSE mortgage rates, suggesting that more information is needed before definitive conclusions can be drawn about the effects of GSEs on mortgage rates.

\section{The GSEs and the Conforming Mortgage Market}

Fannie Mae and Freddie Mac were chartered many years ago as government-sponsored enterprises, or GSEs, partly to correct perceived deficiencies in the mortgage market. (Fannie Mae converted to GSE status in 1968; Freddie Mac was chartered in 1970). In return for a GSE charter, which is not made available to other firms that securitize mortgages, Fannie Mae and Freddie Mac shouldered a public mission: to develop a strong secondary market for mortgages by integrating the mortgage markets with the capital markets and making funds more readily available to mortgage borrowers. These objectives have been largely achieved, and the primary remaining public function of these GSEs is to deliver a part of an implicit federal subsidy to mortgage borrowers. In addition to this function, the GSEs were mandated in 1992 by Congress to make a special effort to ensure that mortgages are provided to low- and moderate-income home buyers.

The charters of Fannie Mae and Freddie Mac also restrict the types of mortgages they may purchase. The restrictions include limiting the loan-to-value ratio to 80 percent or less (unless other measures are taken to limit the credit risk incurred by buying the mortgage) and limiting the size of mortgages purchased. Loans that meet the GSEs' charter restrictions are known as conforming. The conforming loan limit for a mortgage backed by a single-family residence, which is adjusted annually, was $\$ 252,700$ for mortgages originated in 2000. As will be discussed below, the bulk of the nonconforming mortgages securitized by private firms are jumbo mortgages, or mortgages that exceed the GSE size limit.

The most common procedure for securitizing mortgages involves a trade. In many cases, 
although not all, a large originator assembles a pool of conforming mortgages from its portfolio and trades the pool to the GSE in return for securities backed by the mortgages. ${ }^{6}$ In this process, lenders transfer the credit risk of the mortgages to the GSE. In return, the GSE receives a guarantee fee and a guaranteed cash flow from the mortgages (until the mortgage borrower pays off or prepays the mortgage).

The GSEs' charters give them several competitive advantages over private firms when issuing securities, including an exemption from SEC registration requirements and permission to clear GSE securities transactions through the Federal Reserve's book-entry system. In addition, their securities are treated as government securities in the context of the Securities Exchange Act of 1934, which allows many trusts and other non-profit organizations to purchase them. One other notable, explicit advantage is that the risk-based capital requirements for banks' holdings of GSE-issued MBS are substantially lower than for their holdings of private MBS.

The most valuable advantage to the GSEs, however, is the implicit U.S. government guarantee that backs GSE securities. Because these housing-related GSEs were initially established to carry out specific government policies and continue to have government missions, they have a special status in the eyes of many investors. The private market assumes that in almost any adverse circumstances, the government will aid the GSEs; thus, Fannie Mae and Freddie Mac are able to issue debt at a lower cost. This implicit subsidy also gives them an advantage in MBS issuance: the Congressional Budget Office (1996) estimated that an issuer's GSE status lowers interest rates on MBS by 40 basis points from what a private firm would pay on a comparable issue.

\section{Mortgage Securitization by Private Firms}

The presence of the GSEs effectively splits the primary mortgage market into three segments: conforming, jumbo, and other nonconforming mortgages. The conforming market consists of mortgages that are generally low-risk and fall beneath the conforming loan size limit.

${ }^{6}$ The GSEs were issuing mortgage-backed securities (MBS) in volume by the mid1980s. 
The jumbo market is made up of loans that exceed the conforming loan size limit. The remaining mortgages are non-jumbo and nonconforming: some of these may be high risk, such as mortgages with high loan-to-value ratios and no form of mortgage insurance, and some are low risk, such as loans with inadequate documentation but very low loan-to-value ratios. Most private-sector securitizations are backed by jumbo mortgages or mortgages held by "sub-prime" borrowers, the bulk of which have blemished credit histories but adequate assets or income to support a mortgage.

Lacking government backing, private securitizations usually use one of three methods to mitigate credit risk for the holders of the securities: a senior/subordinate structure, overcollateralization, or credit enhancement. ${ }^{7}$ In the first method, the cash flows from the underlying mortgages are split into separate securities or tranches. These securities are usually ordered by their relative riskiness, with the highest-rated tranche bearing little, if any, of the underlying credit risk associated with the mortgages. At the other extreme, an unrated tranche, sometimes referred to as the "toxic waste," is either retained by the originator or sold privately to unregulated purchasers such as hedge funds or private partnerships (or-during the 1980s-to savings and loans). Between the almost riskless and riskiest security can lie many other securities, each with its own risk rating.

Overcollateralization, where the originator backs the security with a stock of mortgages whose value exceeds the face value of the security, is sometimes used in securitization. However, these days the technique is almost always combined with the senior/subordinated structure described above. Finally, credit enhancements for the securities, which protect the investors should the underlying assets default, can be purchased from banks, insurance companies, or even the GSEs.

We now formally model this contrast between the GSE sector, where guarantees are created by the GSEs without an explicit cost imposed on the GSEs (but may present a contingent liability to taxpayers), and the private sector, where credit guarantees are costly for securitizers to create.

${ }^{7}$ For a detailed overview of this market, see Bruskin, Sanders and Sykes (1999). 


\section{Modeling Mortgage Securitization for Conforming Loans}

\section{The Bank and the Mortgage Borrower}

In our model, a mortgage is originated in the first period and securitized or not securitized in the second period. In the third period, the homeowner either pays off the mortgage or defaults and the bank's balance sheet is "marked-to-market." Both the mortgage originator and securitizer are risk neutral, and they know that the expected return from holding a mortgage is:

$$
r_{a}=(1-q) r+q r_{d}
$$

where $\mathrm{r}$ is the mortgage contract rate, $\mathrm{q}$ is the default probability, and $\mathrm{r}_{\mathrm{d}}$ is the return on a defaulted mortgage. We assume that these parameters are identical across mortgages.

We assume the mortgage originator is a bank that has the option of holding the mortgage in its portfolio or swapping it for a mortgage-backed security issued by the mortgage securitizer. The principal and interest on the security are guaranteed by the securitizer. If the bank securititizes the mortgage, it receives a benefit (denoted $\delta$ ) because the security is more easily traded —in other words, is more liquid — than the mortgage.

The cost of government-insured deposits is assumed to be less than the cost of equity, so our bank always funds with deposits if possible (which implies that banks hold the minimum amount of equity capital required by regulators). If the bank holds the mortgage, its weighted average cost of funding is:

$$
f_{m}=\left(1-k_{m}\right) r_{f}+k_{m} r_{e}
$$

where $k_{m}$ is the regulatory minimum capital-to-asset ratio, $r_{f}$ is the yield on deposits, and $\mathrm{r}_{\mathrm{e}}$ is the minimum expected return to capital. If the bank swaps the mortgage for a mortgage-backed security, the cost of funds, denoted $\mathrm{f}_{\text {mbs }}$, is the same, with the exception that the minimum capital ratio becomes $\mathrm{k}_{\mathrm{mbs}}$. Thus, if regulators view the mortgage-backed security as less risky than the mortgage, the cost of funds is lower.

Banking is assumed to be a perfectly competitive industry, in which economic profits are zero. We assume that each borrower's mortgage costs the originator a different amount (denoted $\mathrm{k}_{\mathrm{i}}$ ) to securitize. The cost of making a mortgage securitizable varies across borrowers, 
and is distributed uniformly over $[0, \alpha]$. For example, some borrowers' credit histories can be quickly discovered from computer databases, whereas uncovering other borrowers' histories can be quite time consuming. A bank may be willing to extend credit to a borrower in the latter group without the extensive documentation that would be required to securitize the mortgage.

The bank chooses to securitize the mortgages of borrowers with smaller standardization costs, but not the mortgages of borrowers with higher standardization costs. ${ }^{8}$ In other words, the bank chooses a value for $\mathrm{k}_{\mathrm{i}}$ such that securitized mortgages have $\mathrm{k}_{\mathrm{i}} \in[0, \mathrm{p}]$, where $\mathrm{p}$ is the cutoff value for $\mathrm{k}_{\mathrm{i}}$ that divides the population between securitized and non-securitized mortgages. The proportion of mortgages securitized is then $\mathrm{p} / \alpha$.

The bank's profit function (its expected profit per mortgage originated) is written as:

$$
\Pi_{B}(p)=(1-p / \alpha)\left(r_{a}-f_{m}-t\right)+p / \alpha\left(c+\delta-f_{m b s}-p / 2\right)-c_{m}
$$

where $\mathrm{c}$ is the total return on the mortgage security to the bank (which we will refer to as its effective coupon, which is the stated coupon plus servicing income to the bank), $t$ is the audit cost incurred by an outsider to the bank when determining the value of a mortgage held in portfolio (which the bank takes into account when considering the market value of its portfolio), $\delta$ is the liquidity benefit derived from holding the mortgage as a security, and $c_{m}$ is the marginal cost of originating the mortgage. ${ }^{9}$ The average cost of securitizing mortgages is $\mathrm{p} / 2$.

The bank chooses $\mathrm{p}$ to maximize profits. The first-order condition for this maximization sets $\mathrm{p}$ equal to the difference between the return to holding the mortgage and the return to

${ }^{8}$ In this paper, we ignore the possibility of adverse selection, where banks try to pass mortgages to the securitizer that are expected to perform relatively worse, and the securitizer tries to defend itself. This possibility is discussed at length in Passmore and Sparks $(1996,1997)$. In addition, we ignore the possibility of a corner solution because, while some individual institutions may securitize none or all of their mortgage originations, originators as a whole — as represented by our stylized originator-securitize some mortgages and hold some mortgages.

${ }^{9}$ The effective coupon or yield on a mortgage-backed security for the bank is determined by the coupon, the guaranty fee charged by the securitizer, the servicing relationship between the originator and securitizer, and by other contractual features of the originator/securitizer relationship. For a review of the mechanics of mortgage-backed securitization, see Fabozzi (2001). 
holding the security, or ${ }^{10}$ :

$$
p^{*}=\left(c+\delta-f_{m b s}\right)-\left(r_{a}-f_{m}-t\right)
$$

Thus, equation 4 describes the originator's behavioral response to the securitizer's choice of effective coupon rate, to which our analysis now turns.

\section{The Mortgage Securitizer}

The mortgage securitizer chooses the effective coupon $(c)$ to offer on the mortgagebacked security when it swaps the security for the mortgage. The securitizer guarantees the security from credit losses and holds capital in a reserve to absorb potential losses (or, equivalently, "haircuts" the mortgages so that the dollar amount of securities issued is less than the dollar amount of mortgages held by the securitizer).

The securitizer's profit per originated mortgage is:

$$
\Pi_{S}(c ; p *)=(p * / \alpha)\left(r_{a}-c-k_{s}\left(r_{e}-r_{f}\right)-t\right)
$$

where $\mathrm{k}_{\mathrm{s}}$ is the securitizer's regulatory minimum capital-to-asset ratio. In our model, capital is kept as a "reserve" against possible mortgage defaults and $r_{e}-r_{f}$ is the opportunity cost of holding this capital. The securitizer chooses the effective coupon rate on the mortgage-backed security to maximize profits, while knowing the bank's optimal response in setting the securitization cutoff. Increasing c raises the securitizer's costs, but induces the bank to securitize a higher proportion of mortgages ( $p *$ rises). The securitizer's problem differs depending on whether the securitizer operates in the conforming or nonconforming mortgage market.

\section{The Conforming Loan Market}

As discussed earlier, the mortgages eligible for purchase by Fannie Mae and Freddie Mac

\footnotetext{
${ }^{10}$ Note that mortgages are securitized until the cost of securitizing the marginal borrower equals the difference between the gains to securitization (enhanced liquidity and lower funding costs) and the losses in interest income. Thus, if liquidity is not enhanced and if the capital charge for whole mortgage loans versus mortgage-backed securities is the same, there will be no securitization.
} 
define the conforming market. Using the framework outlined above, we model equilibrium in the conforming market as the pair of $\{\mathrm{r}, \mathrm{c}\}$ such that the economic profits on originated mortgages are zero and the securitizer is choosing the effective coupon yield on mortgage-backed securities to maximize profits, or:

$$
\begin{aligned}
& \Pi_{B}\left(r ; c^{*}, p^{*}\right)=0 \\
& \Pi_{S}\left(c^{*} ; r, p^{*}\right) \geq \Pi_{S}\left(c ; r, p^{*}\right) \forall(r>0,0<c<\infty)
\end{aligned}
$$

If the banking industry is competitive, then its long-run economic profits are equal to zero because any extra profit is dissipated as competition lowers the mortgage rate. ${ }^{11}$ Under the constraint of zero profits, there is an inverse relationship between the yield on the mortgagebacked security and the mortgage rate for any given level of bank profits because a higher level for both implies additional profits to the bank. The zero profit function is smooth and convex to the origin, as shown in figure 1 . Once $\mathrm{c}^{*}$ is determined, the zero profit condition determines $\mathrm{r}^{*}$, as illustrated in the figure.

We use Mathematica to solve these equations algebraically. While Mathematica can easily find solutions to this system, they are lengthy combinations of the parameters described above. However, we can simulate the comparative statics of the system by choosing some realistic parameter values (which are described later in table 1).

To illustrate that the simulation model works as expected, figure 2 shows the effect of varying the regulatory capital requirement over a range of 0 to 65 basis points $\left(\mathrm{k}_{\mathrm{s}}\right.$ in the model above). ${ }^{12}$ As regulatory capital increases, mortgage rates rise slightly while the MBS effective coupon rate falls (upper left panel). The securitizer's profits fall as the required capital-to-asset

\footnotetext{
${ }^{11}$ In the short run, if profits are not forced to zero, securitization may not have much (or any) effect on the mortgage rate, depending on the characteristics of household demand for mortgages. This possibility is explored at length in Heuson, Passmore and Sparks (2000).

${ }^{12}$ Generally, in our simulations we set the securitizer's capital equal to the legislated minimum of 45 basis points. By doing this, we assume that Fannie's and Freddie's government backing means that their debt holders do not care about the level of capital held by the government-sponsored enterprises and only the statutory constraints on capital are binding.
} 


\section{Figure 1 \\ Conforming Mortgage Securitization}

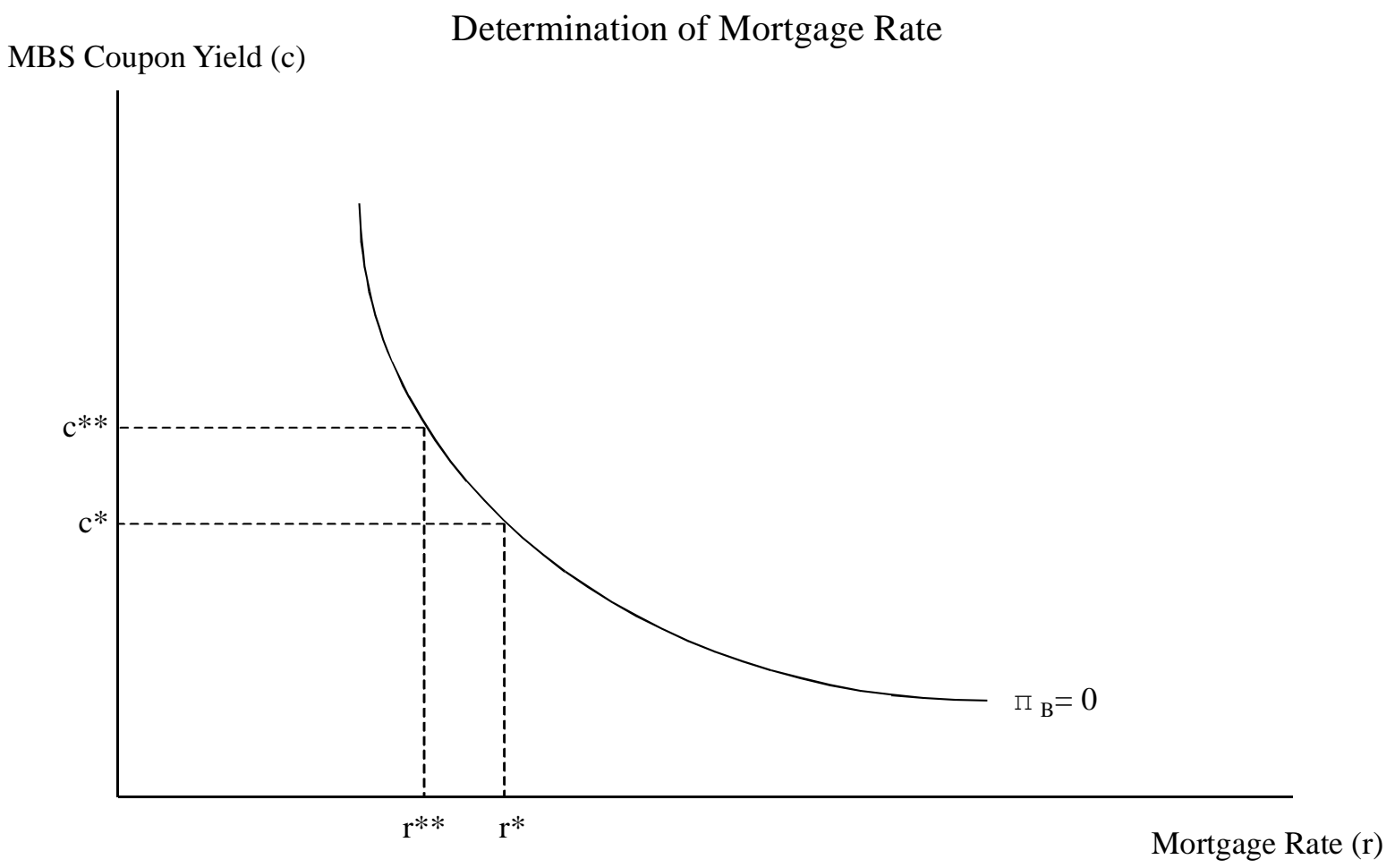

ratio increases (upper right panel), and the securitizer tries to recoup its losses by lowering the effective coupon rate. With a lower MBS effective coupon, mortgage rates rise to maintain the banking industry's economic profits at zero, and the banks have less interest in securitization and thus securitize fewer and fewer mortgages (lower left panel). If the regulatory capital requirement rises high enough, banks cease to securitize because of the low returns to securitization.

\section{A Competitive GSE Securitization Market}

The model above assumes that the securitizer is a monopolist with the ability to maximize profits subject to the banks' response function in choosing the proportion of mortgages to securitize. In the U.S. mortgage market, Fannie Mae and Freddie Mac are duopolists, and there is much debate about whether their behavior more closely resembles competition or monopoly. Given the difficulties of formally modeling a duopoly, we choose here to contrast the 
Figure 2

Effect of Regulatory Capital on Interest Rates

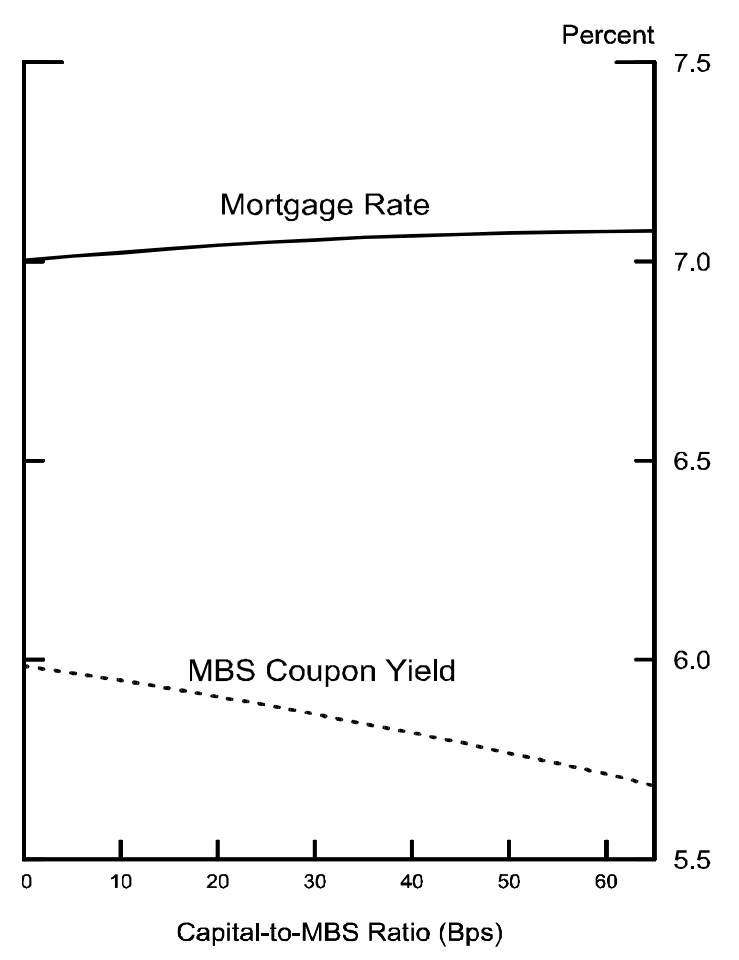

Effect of Regulatory Capital on Mortgages Securitized

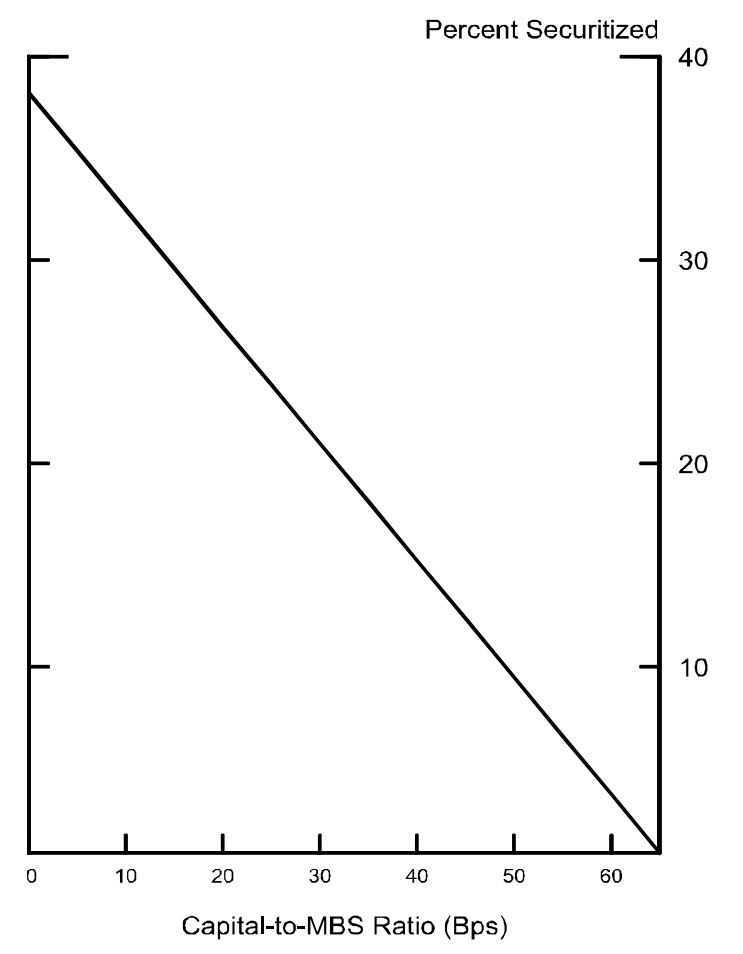

Effect of Regulatory Capital on Securitizer Profits

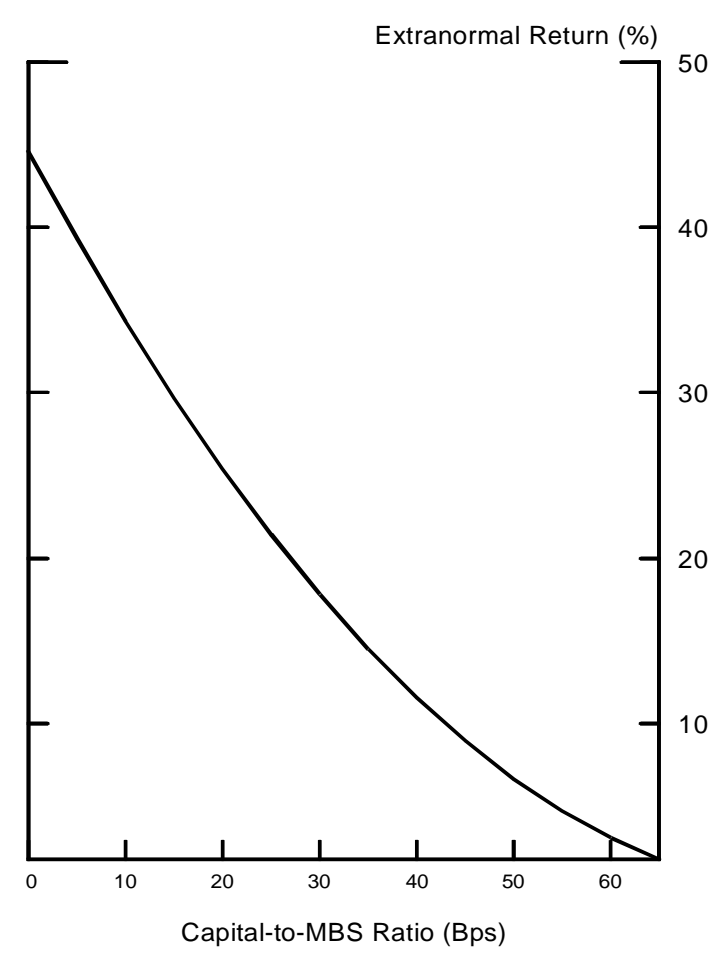

GSE Mortgage Rates

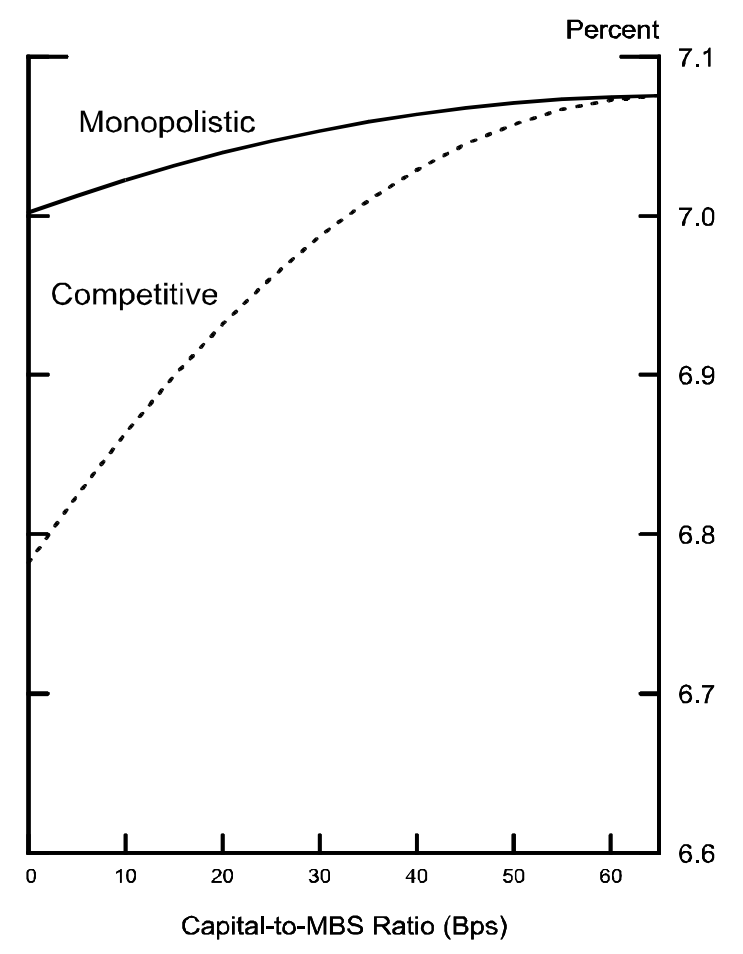


two extremes-monopoly and perfect competition. We model a competitive GSE by assuming that the securitizer's economic profits are driven to zero, so that equilibrium satisfies:

$$
\begin{aligned}
& \Pi_{B}\left(r^{*} ; c^{*}, p^{*}\right)=0 \\
& \Pi_{S}\left(c^{*} ; r^{*}, p^{*}\right)=0
\end{aligned}
$$

With bank profits constrained to zero, a higher MBS yield implies the mortgage rate is lower. This result is confirmed by our simulations, as shown in figure 2 (lower right panel). In the competitive GSE model, mortgage rates are generally lower than in the monopolistic GSEmodel, as the ex ante return to capital is arbitrarily held at 15 percent (a figure slightly above recent returns in the financial services industry) and any excess is passed along to borrowers through the mortgage rate. The difference between the competitive mortgage rate and the monopolistic mortgage rate diminishes as the amount of capital required to be held by the securitizer increases, which drives the securitizer's profitability down to that in the competitive case.

\section{A Graphical Comparison of Mortgage Rates with Competitive versus}

\section{Monopolistic GSEs}

When banks are competitive, the banks' supply of mortgages to the GSEs can be derived from equation (4) and the bank's zero profit condition:

$$
r_{a}=f_{m}+t+c_{m}-\frac{p^{2}}{2 \alpha}
$$

When GSEs behave competitively, their profit per mortgage is invariant to the proportion of mortgages securitized and the resulting competitive equilibrium can be illustrated in a supply and demand diagram (as shown in the upper quadrant of figure 3 ).

When the GSEs behave strategically, they maximize profits with the knowledge that banks will respond to the return on mortgage-backed securities by altering the proportion of mortgages securitized. The tangency between the GSE's iso-profit curves (equation 5) and the bank's decision rule for securitization (equation 4) define this equilibrium, as shown in bottom quandrant of figure 3. Solving algebraically for both solutions yields the result that if GSEs are 
Figure 3

\section{GSE Secondary Market}

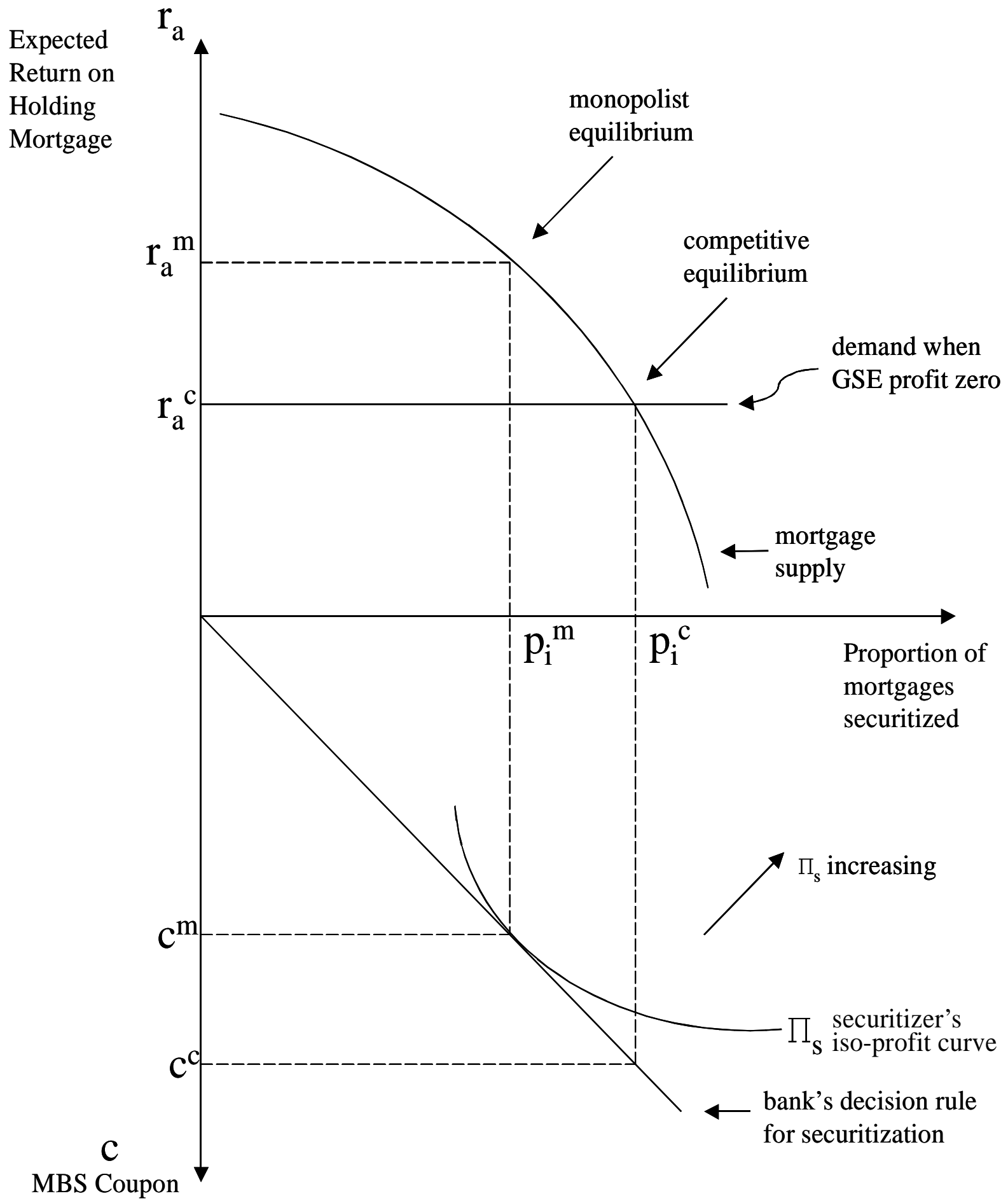


competitive, the proportion of mortgages securitized are greater than when GSEs are noncompetitive, and that mortgage rates are lower when GSEs behave competitively.

\section{The Nonconforming Loan Market}

The securitization of nonconforming mortgages is fundamentally different from the securitization of conforming mortgages because the securitizers do not have government charters and the associated implicit guarantees. In the nonconforming market, investors-both the

shareholders of the securitizer and the holders of the securities - care about how much capital is held by the securitizer because it limits their downside risk. In addition, many investors —particularly trusts, mutual funds, insured depositories, wealthy individuals, and institutions in foreign countries - are unlikely to buy, or are even legally restricted from buying, the security unless a rating agency virtually assures that the credit risk has been removed by giving the security a high rating. Many institutional investors, and almost all retail investors, do not have the ability to analyze the credit risk associated with mortgages. We assume that purchases of securities by these groups of uninformed investors (without the capacity to assess credit risk) create the "depth" and "breadth" in a securities market, and thus enhances its liquidity. ${ }^{13}$

The bank is motivated to securitize because it desires to capture the liquidity value provided by holding a mortgage-backed security instead of a mortgage. However, the liquidity value depends on the credibility of the securitizer's guarantee. If the securitizer does not have either implicit or explicit government backing, the value of the guarantee is determined by the amount of capital or collateral held by the securitizer, because that collateral can be used to offset losses should mortgage borrowers default. Since the value of securitization to many potential

\footnotetext{
${ }^{13}$ There are a variety of reasons investors may prefer more-liquid securities to illiquid loans, and thus are willing to pay for intermediation that converts loans to securities, especially if the investor need not to be concerned about credit risk. For example, mutual funds are required to meet redemptions in seven days or less, which motivates them to hold more liquid instruments. In addition, long-term mutual funds are required to keep 85 percent of their assets in liquid securities. Furthermore, regulatory treatment of mortgage-backed securities relative to mortgage loans is generally more favorable both inside and outside the banking industry. And, at insurance companies, the capital requirement is smaller for securities than for loans.
} 
purchasers of the security is that they need not conduct any credit analysis of the underlying loans, we assume that the capital and collateral are chosen to make the guarantee credible or:

$$
c_{n c}=(1-v) c_{n c}+v\left(\frac{r_{d}}{s}+k_{s n c}\right)
$$

which implies that $c_{n c}=r_{d} / s+k_{s n c}$ where we use, when needed, the subscript nc to indicate nonconforming ${ }^{14}$. If the "good state" occurs (with probability $1-v$ ), then the securities pay their effective coupon, $c_{n c}$. If the "bad state" occurs (with probability $v$ ), then the holders of the securities get the capital held by the securitizer (denoted $k_{s n c}$ ) and the return from the mortgages backing the securitization. Note that $v$ denotes a exogenous default of the securitizer (brought about, for example, by fraud or operations difficulties) and is not related to the defaults of the underlying mortgages - about which the investor knows nothing (and cares to know nothing). ${ }^{15}$

Because of the need to overcollateralize the securities, only a proportion of the cash flow from the mortgages to be securitized is actually turned into securities and is denoted by $s$. The remainder of the cash flow $(1-s)$ accrues to a residual tranche that is not converted into securities. Since $r_{d}$ is constant across all mortgages, it is the value of the collateral to the security holders if the securitizer defaults. In the bad state, the bank, which holds the claim to the residual tranche, gets nothing. ${ }^{16}$

\footnotetext{
${ }^{14}$ Of course, in most non-GSE securitization structures, the securities holders must rely only on the loss absorption of the subordinate piece of the security and do not recourse to the capital of the securitizer. However, in practice, originators/securitizers sometimes pledge additional collateral or inject cash into securitization trusts when the existing collateral become impaired because they do not want to hurt their reputation for providing investment-grade securities to the market. Regardless of the form of the contract, we believe the purchasers of the high credit quality portions of the trust demand the equivalent to a risk-free security and that prices and contracts will reflect this demand.

${ }^{15}$ The uninformed investor can be thought of as caring only about the rating given the security by an independent rating agency, which certifies that the securitizer has sufficient resources to make timely payments on the securities.

${ }^{16}$ In practice, the residual tranche might be sold to a mortgage servicer that specializes in handling foreclosed or delinquent mortgages. Regardless, the bank represents "informed investors," who receive the economic value associated with the residual tranche because they invest in the technology to assess the credit risk associated with pools of mortgage loans.
} 
The probability that the securitizer defaults (v) is irrelevant to the uninformed investor in the MBS (and thus it falls out of equation 9). Uninformed investors are assumed to desire a security where the value is readily determined, and thus the focus only on the securitizer's capital and overcollateralization. These investors do not desire to become knowledgeable about the characteristics of the underlying mortgages.

As discussed earlier, private-sector securitizations usually break the cash flows from the underlying mortgages into separate securities, and the equation above incorporates this contract design. The contract between the securitizer and the originator is straightforward: the securitizer issues a security based on only the fraction of the cash flow of the mortgages that the bank desires to securitize, but the security holders have claim to all of the collateral backing these mortgages should the mortgages default, enhancing the ex ante return from the securities.

As in the conforming market, we assume that the mortgage rate in the nonconforming market is set so that economic profits per mortgage originated by the bank are zero (and the choice of which mortgages to securitize maximizes bank profits). (The bank can be viewed as having two departments, as many do—one that originates and securitizes conforming mortgages and one that originates and securitizes nonconforming mortgages.) But unlike in the monopolistic conforming market, we assume that competition among mortgage securitizers drives their profits to zero.

The bank's profits, as in the case of GSE securitization, depend on the returns from the mortgages it holds and those it securitizes. The returns on the mortgages held directly are parallel to those in the GSE case, but returns from securitization are different because of the need to account for the two tranches. Two tranches—one investment grade securities (accounting for s percent of the mortgages securitized and with a payoff to the bank of the MBS effective coupon yield plus the liquidity premium) and the other "toxic waste" (accounting for $1-s$ percent of the mortgages securitized and with its payoff the residual mortgage cash flow when a mortgage does not default and zero when a mortgage does default) — are embedded in the bank's profit function as follows:

$$
\Pi_{B}\left(s, p_{n c} ; c\right)=\left(1-p_{n c} / \alpha\right)\left(r_{a_{n c}}-f_{m}-t\right)+p_{n c} / \alpha\left[s\left(c_{n c}+\delta\right)+(1-s)(r(1-q))-f_{m}-p_{n c} / 2\right]-c_{m}
$$


Note that we assume that the bank regulator is not "fooled" by the securitization, and applies the capital weight for all the mortgages to the holder of the residual tranche.

As in the conforming market, the bank maximizes profits by choosing the proportion of mortgages to securitize, $\mathrm{p}_{\mathrm{nc}}$, producing the first-order condition:

$$
\frac{\partial \Pi_{B}}{\partial p_{n c}}=s\left(c_{n c}+\delta\right)+(1-s)(r(1-q))-f_{m}-\left(r_{a}-f_{m}-t\right)-p_{n c}=0
$$

This first-order condition simply equates the marginal profit of securitizing to the marginal profit of holding a mortgage in portfolio.

The securitizer's profit function, which incorporates s but not (1-s) because the securitizer produces the securities and the bank holds the residual tranche, is written as:

$$
\Pi_{s}\left(k_{s n c} s ; p^{*}\right)=(1-v)\left(p_{n c}^{*} / \alpha\right)\left[s\left[(1-q) r_{n c}+q \frac{r_{d}}{s}-c_{n c}\right]-\left(r_{e}-r_{f}\right) k_{s n c}-t\right]
$$

Note that if a mortgages defaults, the securitizer receives all of the value of the collateral underlying the mortgage and the holder of the residual tranche (in this case, the bank) receives nothing. Should the securitizer default, all of the value (both capital and mortgage collateral) goes to the securities' holders (the uninformed investors).

Unlike in the GSE case, the securitizer does not choose $c_{n c}$. In the nonconforming case, the only purpose of the securitizer is to help the bank capture the liquidity premium from securitization. Competition among securitizers-who are competing to be the bank's securitizer-causes securitizer capital, $\mathrm{k}_{\mathrm{snc}}$, to adjust until economic profits are zero.

In equilibrium, uninformed investors hold the securities and informed investors hold the residual tranche. Since informed investors always have the choice of holding the security (and all agents are risk-neutral), the effective coupon rate is set so that the expected return to the bank of holding the security equals the return to holding the residual tranche of the securitization. Thus, the following equation characterizes equilibrium:

$$
c_{n c}+\delta=r(1-q)
$$


Combining the bank's zero profit function (by setting equation 9 to zero), its first-order condition (equation 10), and equation 12, we obtain the solutions for $\mathrm{c}^{*}{ }_{\mathrm{nc}}, \mathrm{p}^{*}$, and $\mathrm{r}^{*}$. Combining these solutions with the securitizer's zero profit condition (equation 11) and the equation for creating a risk-free security (equation 8), we find solutions for $\mathrm{s}$ and $\mathrm{k}_{\mathrm{snc}}$.

\section{A Graphical Comparison of Three Possible Equilibrium Mortgage Rates}

In our model of the nonconforming mortgage market, we assume securitizers are competitive and, in essence, this model is similar to the competitive GSE model - the primary difference is that nonconforming securitizers have a higher cost structure because of their lack of an implicit government guarantee. As shown in the upper quadrant of figure 4, this higher cost structure yields a higher primary mortgage rate than the competitive GSE mortgage rate. However, the jumbo mortgage rate may be higher or lower than the monopolistic GSE mortgage rate. Similarly, the proportion of mortgages securitized in the jumbo market will be less than the proportion in the competitive GSE market, as shown on the horizontal axis of figure 4.

\section{Simulation Results}

Using the model developed above, we simulate both the differences between effective mortgage and MBS rates for all three types of markets (monopolistic GSE, competitive GSE and nonconforming mortgages) and the difference between GSE and nonconforming market mortgage rates. There are eleven exogenous parameters in these models, some of which have values that are well-known. For example, the minimum risk-adjusted capital requirement on banks for mortgages and for private mortgage-backed securities with a high investment-grade rating is 4 percent $\left(\mathrm{k}_{\mathrm{m}}\right)$, the minimum risk-adjusted capital requirement for banks on GSE mortgage-backed securities is 1.6 percent $\left(\mathrm{k}_{\mathrm{mbs}}\right)$, and the minimum capital requirement on Fannie Mae and Freddie Mac for mortgage-backed securities is 45 basis points $\left(\mathrm{k}_{\mathrm{s}}\right)$.

Other parameters are independent of the particular mortgage system. For example, we assume that the ex ante risk-adjusted return to capital is 15 percent $\left(\mathrm{r}_{\mathrm{e}}\right)$ and that a bank's cost of 
Figure 4

\section{Nonconforming Secondary Market}

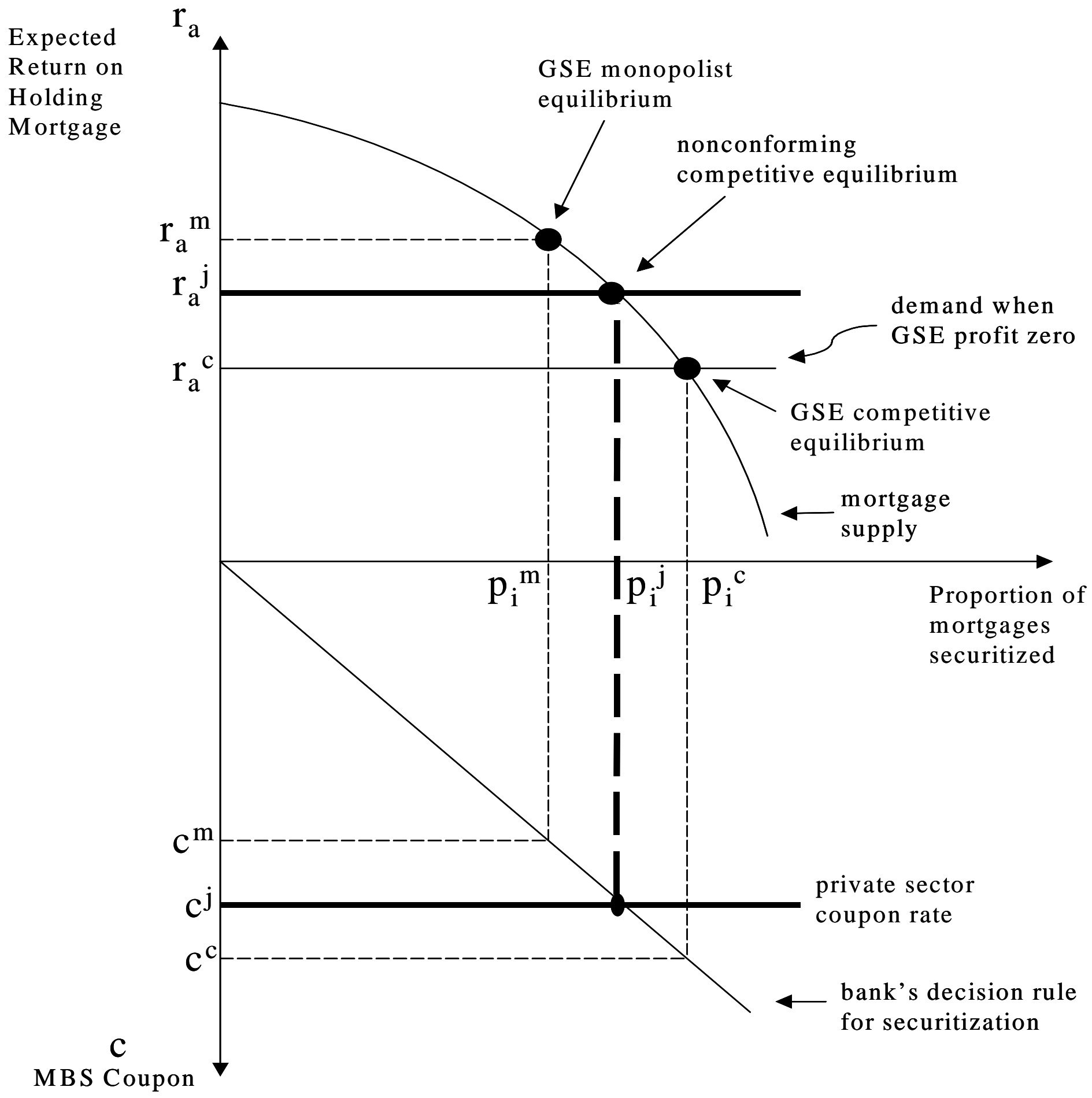


deposits is 6 percent $\left(\mathrm{r}_{\mathrm{f}}\right)^{17}$. It seems unlikely that either of these values would vary by mortgage system, although different values for these parameters — even when the same for both mortgage systems — can have different effects in the two systems.

Finally, six of the parameters may or may not vary by type of mortgage. Three of these parameters can be chosen with reference to some previous empirical work. The expected annual default rate is assumed to be 10 basis points (the GSEs' "serious delinquency rates" are about 50 basis points, but actual default rates are far smaller), the marginal cost of mortgage origination is assumed to be 1 percent (an amount consistent with industry studies), and the loss incurred on a defaulted mortgage is 20 percent of the balance (so that $r_{d}=0.8$ ). ${ }^{18}$

The three other parameters have unknown values and thus are chosen based on the authors' beliefs about what might be reasonable. The value to the bank of the liquidity from holding a security is assumed to be 50 basis points $(\delta)$, the cost of an outsider (an institution that did not originate the mortgage) evaluating a mortgage (denoted $t$ in the model) is 15 basis points, and the maximum cost of converting a mortgage into a security $(\alpha)$ is 100 basis points.

By varying the parameters described above, we simulated the spread between effective mortgage and MBS rates (tables 1A and 1B). The parameter that varies in the simulation is described in columns 1 and 2 on the table. The range over which the parameter varies is given in column 3 , and column 4 shows the value of the parameter when other parameters are chosen to vary.

Table 1A covers the monopolistic and competitive GSE cases. For each case, we used three different values of a parameter-the minimum in the range, the midpoint, and the maximum. Using three cases provides a sense of how varying the parameter affects the mortgage-MBS spread. We also provide the proportion of mortgages securitized for each case in this table.

\footnotetext{
${ }^{17}$ Our model ignores interest rate risk or maturity-mismatch risk. We solve the latter problem by assuming that the model periodicity is annual over a long horizon. Thus, the appropriate deposit rate is for a long-term deposit or bond. As for interest rate risk, it is outside the scope of this model but generally one would add from 60 to 120 basis points to our simulated mortgage rates to account for the prepayment option.

${ }^{18}$ See Canner, Passmore and Surette (1996).
} 
Given how we define effective rates, the spread between mortgage and MBS rates in the conforming market is equivalent to the guarantee fee charged by the GSEs, which generally runs between 17 and 23 basis points for most transactions between GSEs and mortgage originators. In our simulations for the monopolistic GSE case (columns 5 through 7), the mortgage-MBS spread ranges from 27 basis point to 77 basis points, somewhat higher than the fee normally charged by the GSEs in practice. Also, in this case, the proportion of mortgages securitized ranges from 5 percent to 55 percent. The actual proportion of the mortgage market securitized by the GSEs is difficult to estimate, but it appears to range between 45 percent and 65 percent. ${ }^{19}$ Finally, in the monopolistic case, securitizers earn positive economic profits. The simulated GSE's accounting profits (columns 11 to 13) vary from a low of 15 percent to a high of 45 percent, with most values around 24 percent. Fannie Mae's and Freddie Mac's return to equity has average around 25 percent during the past decade.

In the competitive GSE case (columns 8 to 10), the simulated spreads run from 7 basis point to 37 basis points, with most values in the low twenties. The proportion of mortgages securitized varies from 9 percent to 109 percent (a value that is "out of bounds"), with most between 50 percent to 70 percent. By definition, economic profits are zero in the competitive case.

In both the monopolistic and competitive cases, the liquidity value of securitization creates the large changes. In the monopolistic case, these changes are reflected in the mortgageMBS rate spreads, whereas in the competitive case they are reflected in the proportion of mortgages securitized. The monopolist captures the liquidity premium, while the competitor passes it on in the mortgage rate.

The nonconforming mortgage market is described in table 1B. There are more endogenous variables in this case; thus, we present the simulations in a different format from that of the other table 1A. Here, we run 100 simulations for values equally spaced across the range for the parameter (holding all other parameters at their fixed value, as described in column 4) and present the mean and standard deviation of the simulation results.

\footnotetext{
${ }^{19}$ See pages 3-5, The 2001 Mortgage Market Statistical Annual, op. cit.
} 
Unfortunately, for this market, there are no readily available industry statistics to compare with the simulation results. As shown in columns 5 through 7, mortgage rates in our simulations are about 7.5 percent (recall, these rates do not include a charge for the prepayment option). Like the competitive GSE spread, the mortgage-MBS spread is relatively constant across simulations (at 61 basis points) because the securitizer simply "marks up" the costs of securitization to provide the return on capital (column 8). But unlike the GSE market, securitization occurs for only a small percentage of the nonconforming mortgages, reflecting the higher cost of credit enhancement required in this purely private-sector endeavor (column 9).

The key to private sector securitization is the provision of the residual tranche (column 10). In these simulations, 78 percent of the cash flow from the mortgages purchased by the securitizer is issued as securities, while the remaining 22 percent is held to protect the first tranche against losses. The securitizer's capital-another layer of protection for the first tranche security holders_runs between 3.6 percent to 4.1 percent of mortgage assets (column 11). Investors in nonconforming MBS have both recourse to this capital and priority over the holders of the residual tranche for the collateral should the mortgage securities default. Combining the securitizer's capital with the collateral backing the residual tranche, the first tranche security holders effectively have claim to about 21 percent of the value of the mortgages (column 12). Given that in the case of default, the loss rate is between zero and 40 percent, the first mortgage holders reasonably expect no losses on their securities.

\section{Simulating the Conforming-Nonconforming Mortgage Spread}

We use a a similar simulation exercise to investigate the spread between conforming mortgage rates and nonconforming mortgage rates (table 2). We vary the parameters in the same way as before (columns 1 through 4). Column 5 shows the mean and standard deviation of the difference between the nonconforming and monopolistic conforming mortgage rate for 100 simulations that span the range of parameters (as was done in table 1B). It is striking how little difference there is in the means of the spreads across parameters for the monopolistic case-all of these spreads are less than 10 basis points (column 5). When the GSEs are treated as competitive, the resulting mortgage rate is always somewhat lower than when they are treated as monopolists, and the spread between the nonconforming and conforming rate is centered around 
17 basis points, with a standard deviation that suggests a range from about 5 to 40 basis points (column 6).

Rather than focusing on the average differences, we might look instead at the maximum difference between the nonconforming rate and the conforming rate for any particular parameter value (columns 7 and 8). Here, again, the spreads in the monopolistic case are relatively small, whereas for the competitive case they are larger. Again, the value of liquidity and the bank's regulatory capital requirement on a mortgage portfolio can yield sizable differences in rates.

We also compute the maximum difference between the nonconforming mortgage rate and the GSE rate, where either can be derived from any value of the parameter over the relevant range (columns 9 and 10). As noted earlier, some of these parameters are unlikely to be different in actual markets. For example, the bank's cost of deposits or the risk-adjusted return to capital should not depend on whether the bank holds conforming mortgages or nonconforming mortgages. Other parameters, such as the marginal valuation costs or fixed costs of origination, might arguably differ between conforming and nonconforming mortgage originations because of the greater volume or greater standardization of conforming mortgages. Finally, some parameters likely are different across the GSE and private-sector markets. These parameters include the regulatory capital requirements imposed on banks, which are usually lower when banks hold GSE mortgage-backed securities than when they hold private-sector mortgage-backed securities, and the liquidity of the markets, where GSE mortgage-backed securities have agency status, allowing them to be purchased by a variety of trusts and other fiduciaries, whereas privatesector securities lack this status.

The liquidity premium is perhaps the most interesting parameter of the model. Recall that the liquidity premium is the value to the originator of holding a mortgage as a security compared with holding it as a loan ${ }^{20}$. The liquidity advantage of the GSE-created securities arguably stems directly from the GSE's implicit government backing. If liquidity is mainly the result of size, and if the large sizes of the GSEs are mainly a result of their advantages over

\footnotetext{
${ }^{20}$ There are a variety of reasons different securities may have different market liquidity. For example, Grossman and Miller (1988) point to greater frequency of trading, Pagano and Roell (1996) suggest that transparency of pricing is important, and Glaeser and Kall (1997) develop a model showing that more information about a security may either increase or decrease liquidity.
} 
private-sector securitizers, then their liquidity advantage can be seen as an extension of their GSE status. However, if their liquidity advantage arises mainly because of better execution and management of securities transactions, then the advantage may not be associated with GSE status. ${ }^{21}$ Regardless, if this parameter differs across nonconforming and conforming mortgages, the resulting mortgage rate spread can be large.

All things considered, if GSE behavior is competitive or if there are stark differences between parameter values across the nonconforming and conforming mortgage markets, then many other parameters, including banks' cost of deposits, bank capital standards, and the fixed costs of mortgage origination, can yield big differences in simulated mortgage rates (rows 2, 3 and 10; columns 8 and 9). However, as mentioned above, it is difficult to see why the cost of deposits would vary by the type of mortgage originated by the bank. Similarly, large differences in the minimum bank capital requirements can generate large differences in mortgage rates, but this value is pegged at 4 percent for both conforming and nonconforming mortgages.

Differences in the fixed costs of origination can create large differences in mortgage rate spreads. This cost, however, is relatively uninteresting analytically because it is simply passed through to the mortgage borrower. Thus, if origination costs for nonconforming mortgages were, for example, 50 basis points higher, the nonconforming mortgage rates would be about 50 basis points higher.

Other parameters that may differ across mortgages - the marginal valuation cost, annual mortgage default rate and the losses on a defaulted mortgage — can create differences in mortgage rates that are large enough to account for observed differences in rates. However, while these costs may well vary significantly between some jumbo and conforming mortgages, there is some evidence that the average the credit quality of jumbo mortgages eligible for securitization and conforming mortgages does not differ much (see Mansukhani and Kramer, 2000).

\footnotetext{
${ }^{21}$ The debate about the source of the liquidity advantage is noted in the U.S. Treasury's report on Fannie and Freddie: "In comments provided to the Treasury, Freddie Mac stated that a funding advantage of 30 basis points in issuing mortgage-backed securities was reasonable, but this was not a fair measure of their GSE benefits since their securities also benefit from a liquidity advantage. Any liquidity premium accruing to the GSE's mortgage-backed securities however, reflects to some (probably large) degree, liquidity advantages derived from their GSE status." (U.S. Treasury, 1996, p.31)
} 
How to interpret these simulation results depends on one's view of the similarity between conforming and nonconforming mortgages. If these mortgages are identical, monopolistic behavior by the GSEs yields small differences between conforming and nonconforming rates (up to 15 basis points), whereas competitive behavior might yield differences as large as 60 basis points. If these mortgages are different, then large differences in rates emerge regardless of the competitive behavior of the GSEs.

Theoretically, the nonconforming mortgage rate can be below the GSE conforming mortgage rate. If the liquidity benefits of securitization are small and the regulatory capital advantages granted to securitization of minimal, then the value of the implicit government guarantee does not yield a substantial cost advantage to the GSEs. Of course, with the small liquidity or capital benefits, few mortgages would be securitized in any case. For example, if liquidity benefits are assumed to be zero but the capital advantage is large (providing a motivation to securitize some mortgages), then the simulated value of the nonconforming mortgage rate can be a few basis points below that of the GSE mortgage rates (this is true for both the monopolistic and competitive GSE rates) for simulations where the other parameters are within the ranges described in the tables. Only a small percent of conforming mortgages are securitized in these cases, but GSE securitizer profits are positive.

\section{An Empirical Investigation of the Jumbo-Conforming Spread}

The bulk of nonconforming mortgages that are securitized are jumbo mortgages. The difference between rates paid on jumbo mortgages, which are too large to be securitized by the GSEs, and those paid on conforming mortgages is often used as a proxy for the influence of GSEs on mortgage rates, and we will use it here as such. However, the jumbo mortgage rate is not a direct measure of the mortgage rate that would prevail if the GSE subsidy did not exist. For example, the poorer liquidity of jumbo mortgage-backed securities might be significantly improved if the jumbo and conforming mortgage markets were combined. As shown above, the liquidity for the securities makes a significant difference in the resulting mortgage rates.

On the other hand, to the degree that homeowners can substitute between jumbo and 
conforming mortgages, lower mortgage rates in the GSE market may also push down mortgage rates in the jumbo market, implying that current jumbo rates might understate the possible rise in mortgage rates were GSEs not present (assuming that all mortgages would rise to the "no-GSE" jumbo rate without GSEs). As shown below, we attempt to control for this effect by looking only at jumbo mortgages that are substantially above the GSE size limit.

The primary source of data on mortgage rates is the Mortgage Interest Rate Survey (MIRS), a large monthly survey of terms on single-family first mortgages, which is collected by the Federal Housing Finance Board. This loan-level data set is gathered from a number of thrifts, as well as some commercial banks and mortgage companies. The data collected for each mortgage include the outstanding principal, the contract interest rate, fees, the effective interest rate, the type of mortgage (adjustable or fixed), term to maturity, loan-to-value ratio, and state of origination.

We attempt to select data from MIRS so that the jumbo and conforming mortgages used in our analysis are as similar as possible. We control for a variety of factors by limiting our analysis to the state level. For example, default risk, in particular, is an important determinant of the nonconforming-conforming spread, and default rates and foreclosure laws vary by state. Moreover, state variation in laws concerning matters related to mortgages (e.g. title insurance, escrow accounts, etc.) can result in small variations in mortgage rates-variations that may be a sizable part of the nonconforming-conforming spread. Finally, a small number of mortgages within a state may indicate the jumbo market within the state is too thin to provide a reliable gauge of the jumbo rate in a hypothetical well-functioning market.

Unfortunately, the average monthly sample sizes vary substantially across states and are often very small. For jumbo loans, California offers a sample averaging around 613 loans per month. For the rest of the states, however, samples are sparse. Illinois, Maryland, New Jersey, Virginia, and Washington each average between 60 and 70 jumbo mortgages per month in the survey, but 30 states have fewer than 15 observations per month for jumbos.

As a result, we choose to focus only on loans originated in California (as was done in some of the earlier studies making this comparison). We also select only 30-year fixed-rate mortgages with principal of at least $\$ 125,000$ and with loan-to-value ratios no greater than 80 
percent. We set a minimum size on conforming mortgages because smaller mortgages may be more costly to underwrite than larger mortgages. As for the loan-to-value ratio, it is perhaps the best measure of credit risk for the mortgage per se and, by restricting it to 80 percent or less, we limit our discussion to rather ordinary low-risk mortgages that potentially could be purchased by a GSE. Even so, without additional information, such as information about the borrower's credit history, we cannot be certain that the mortgage is truly conforming.

We choose jumbo loans that are less than twice the GSE loan limit but greater than $\$ 20,000$ over that limit. We set a maximum size because extremely large mortgages are often unique and fall within the realm of "private banking." We exclude mortgages within $\$ 20,000$ of the GSE loan limit because most mortgage holders with low-risk loans would usually stretch to fall under the GSE limit to get the generally lower mortgage rate or split their mortgage into a conforming first mortgage combined with a second mortgage. Thus, a mortgage within this limit might be unusual; otherwise it would have been split into a conforming first mortgages and a small second mortgage.

Finally, we screen the mortgage rate data and delete mortgages with rates greater than 12 percent or less than 5 percent because for fixed-rate mortgages over this time period, values outside this range are likely data-entry errors or (on the high end) represent "subprime" mortgages. We also limit our time frame to 1992 through 1999, partly because private-sector securitization is a relatively recent phenomenon and partly because MIRS underwent a substantial revision in 1991 that improved the data collection, but made comparison to earlier years difficult. With this screened data set, observations are even sparser, with California having an average of around 308 conforming loans and 102 jumbos per month. ${ }^{22}$

As shown in the top panel of figure 5, we find that the difference between the median jumbo and conforming rates varies considerably over the 1992-1998 period. However, this spread is consistently positive with the exception of 1994. Over the entire period, the mean difference of this spread is 18 basis points. Excluding the years 1992 through 1994 (because one

\footnotetext{
${ }^{22}$ After these screens are applied, no other state has more than twenty jumbo loans per month and all but five have fewer than ten. The screen that removes adjustable-rate mortgages accounts for much of the drop in the number of jumbo loans. Unfortunately, the terms on adjustable-rate mortgages are so varied it is not possible to determine how to aggregate these mortgages.
} 


\section{Spread Between Conforming and Jumbo Interest Rates in California*}

Difference Between Median Rates

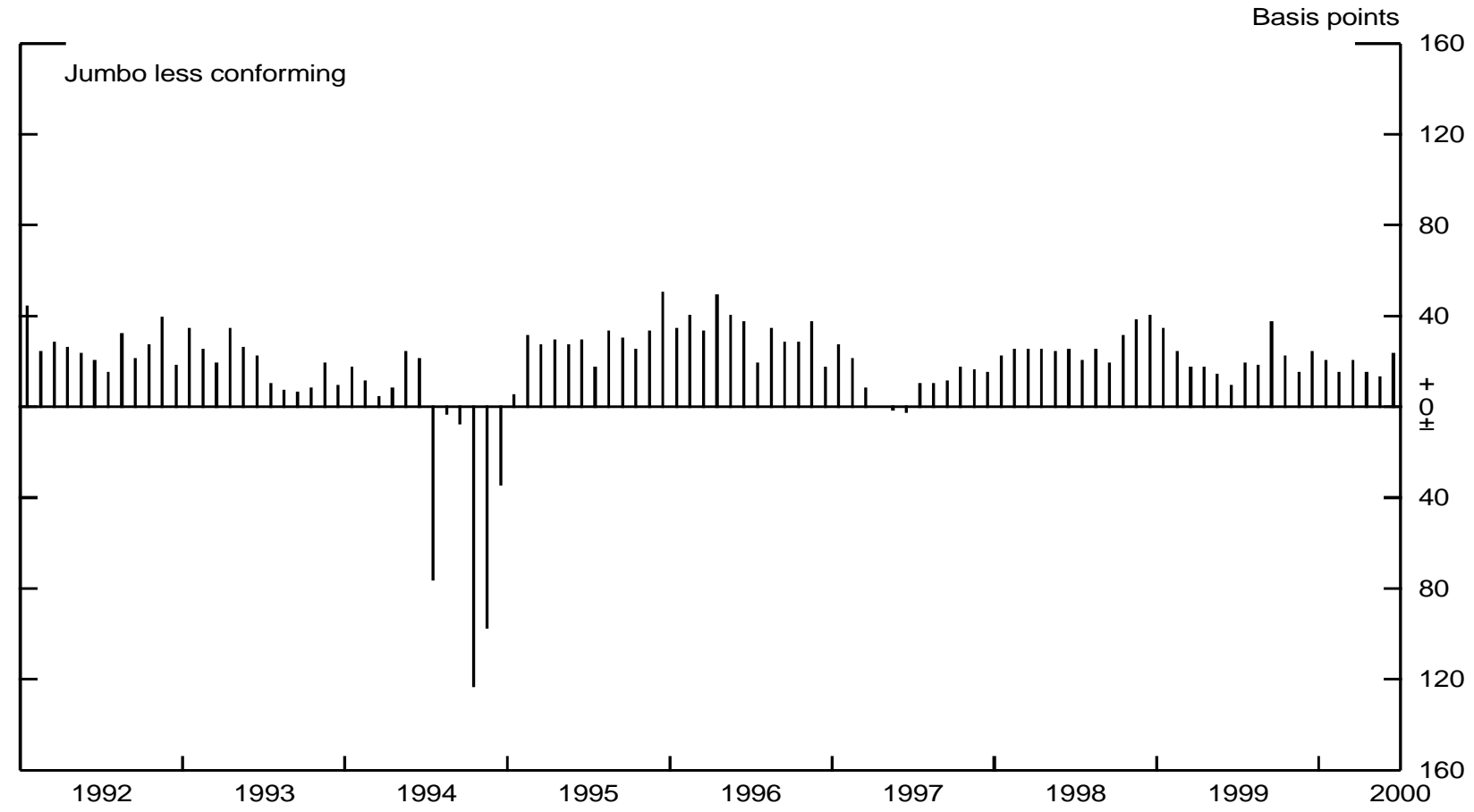

Difference Between Median Rates

Set To Zero Where Statistically Insignificant

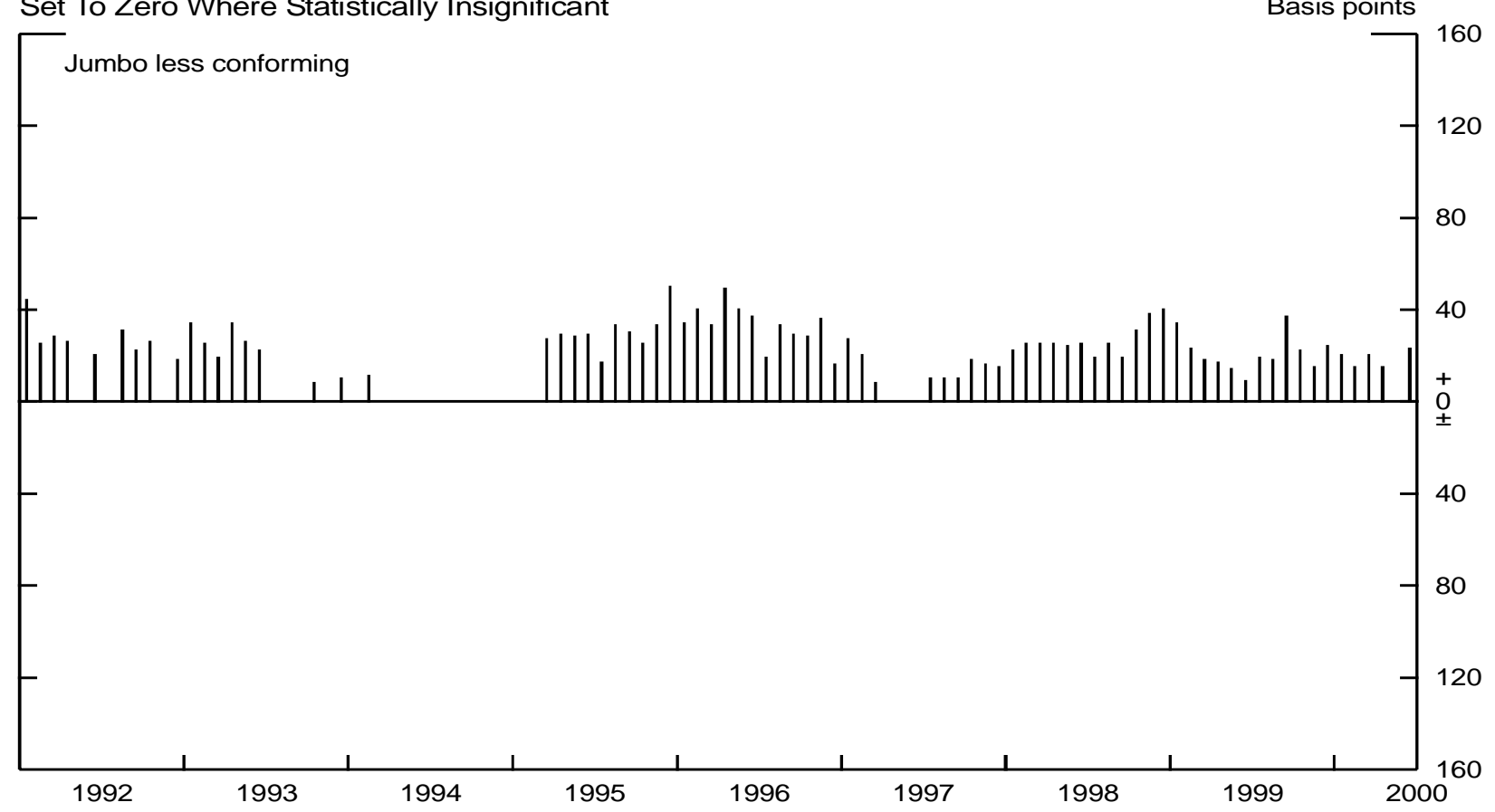

${ }^{*}$ Based on rates for $30-y r$ FRMs of at least $\$ 125,000$ with LTV of $80 \%$ or more and interest rate between $5 \%$ and $12 \%$. Jumbo mortgages range from $\$ 20,000$ above Fannie and Freddie's purchase limit to twice the limit. 
might think the negative spreads observed during 1994 were unusual and signaled a transition to a new regime in MBS pricing) results in a mean difference of 23 basis points.

Unfortunately, the substantial variation in this spread means that we have little confidence in any point estimate of the spread. For example, the standard deviation of the mean difference over the entire sample is 24 basis points, greater than the point estimate of 18 basis points. When the years 1992 through 1994 are removed, the standard deviation falls to 11 basis points. Using the rule of thumb that two standard deviations cover almost all possible observations, this measure would suggest that the spread ranges from zero to around 50 basis points.

Since we have a cross-section of mortgages for each month, we can perform a test to see if the difference between the two median rates in a given month is statistically significant. Doing so, we find that the large negative values observed in 1994 are insignificant because the number of jumbo loans during these months is small, making the standard error of the median estimate large. If we set the spreads in 1994 to zero, the mean difference between the median conforming and jumbo rate is little changed, at 19 basis points. And, again, the standard deviation is large-13 basis points.

\section{Conclusion}

Our data analysis indicates that the typical spread between mortgages conforming for purchase by Fannie Mae or Freddie Mac — the two largest mortgage-related GSEs_-and mortgages that are not eligible for purchase by these GSEs is between 18 and 23 basis points, although the range of this difference varies substantially over time, suggesting there can be little confidence in these type of point estimates. Regardless, our simulations suggest a similar difference if conforming and nonconforming mortgages are identical in their liquidity and other characteristics, and if the GSEs behave as perfect competitors. If nonconforming mortgages are either less liquid when converted to securities or more expensive to originate or evaluate than conforming mortgages, then our simulations suggest that the observed mortgage spread is smaller than would be realized if Fannie and Freddie behaved competitively. 


\begin{tabular}{|c|c|c|c|c|c|c|c|c|c|c|c|c|}
\hline \multicolumn{13}{|c|}{$\begin{array}{l}\text { Table 1A } \\
\text { Simulated Mortgage-MBS Spreads, Securitization Proportions and Profits for GSE Markets } \\
\text { Changes in these statistics in Response to Changes in Exogenous Parameters }\end{array}$} \\
\hline \multirow[t]{3}{*}{$\begin{array}{c}(1) \\
\text { Parameter }\end{array}$} & \multirow[t]{3}{*}{$\begin{array}{c}(2) \\
\text { Symbol }\end{array}$} & \multirow[t]{3}{*}{$\begin{array}{l}\text { (3) } \\
\text { Parameter } \\
\text { Range Used in } \\
\text { Simulation }\end{array}$} & \multirow[t]{3}{*}{$\begin{array}{c}\text { (4) } \\
\text { Parameter } \\
\text { value used } \\
\text { when } \\
\text { parameter is } \\
\text { fixed }\end{array}$} & \multicolumn{6}{|c|}{$\begin{array}{c}\text { Difference between the Mortgage Rate and the MBS } \\
\text { Coupon at Varying Parameter Values with } \\
\text { Corresponding Proportion of Mortgages Securitized in } \\
\text { Parentheses. }\end{array}$} & \multicolumn{3}{|c|}{$\begin{array}{c}\text { Securitizer's Profits at Varying } \\
\text { Parameter Values }\end{array}$} \\
\hline & & & & \multicolumn{3}{|c|}{$\begin{array}{l}\text { Monopolistic Case } \\
\text { (Spread in Basis Points; } \\
\text { Proportion in Percent) }\end{array}$} & \multicolumn{3}{|c|}{$\begin{array}{l}\text { Competitive Case } \\
\text { (Spread in Basis Points; } \\
\text { Proportion in Percent) }\end{array}$} & \multicolumn{3}{|c|}{$\begin{array}{l}\text { Monopolistic Case } \\
\text { (Basis Points) }\end{array}$} \\
\hline & & & & $\begin{array}{l}(5) \\
\text { Min }\end{array}$ & $\begin{array}{l}(6) \\
\text { Mid }\end{array}$ & $\begin{array}{l}(7) \\
\operatorname{Max}\end{array}$ & $\begin{array}{l}(8) \\
\text { Min }\end{array}$ & $\begin{array}{l}(9) \\
\text { Mid }\end{array}$ & $\begin{array}{l}(10) \\
\operatorname{Max}\end{array}$ & $\begin{array}{l}(11) \\
\text { Min }\end{array}$ & $\begin{array}{l}(12) \\
\text { Mid }\end{array}$ & $\begin{array}{l}(13) \\
\operatorname{Max}\end{array}$ \\
\hline $\begin{array}{l}\text { 1. Liquidity value of } \\
\text { securitization }\end{array}$ & $\delta$ & $\begin{array}{l}0 \text { to } 100 \text { basis } \\
\text { points }\end{array}$ & $\begin{array}{l}50 \text { basis } \\
\text { points }\end{array}$ & $\begin{array}{l}27 \\
(5)\end{array}$ & $\begin{array}{c}54 \\
(30)\end{array}$ & $\begin{array}{c}77 \\
(55)\end{array}$ & $\begin{array}{l}22 \\
(9)\end{array}$ & $\begin{array}{c}22 \\
(95)\end{array}$ & $\begin{array}{c}22 \\
(109)\end{array}$ & 15 & 24 & 45 \\
\hline $\begin{array}{l}\text { 2. Bank's cost of } \\
\text { deposits }\end{array}$ & $\mathrm{r}_{\mathrm{f}}$ & $\begin{array}{l}4 \text { percent to } 8 \\
\text { percent }\end{array}$ & 6 percent & $\begin{array}{c}53 \\
(31)\end{array}$ & $\begin{array}{c}52 \\
(30)\end{array}$ & $\begin{array}{c}50 \\
(29)\end{array}$ & $\begin{array}{l}22 \\
(62)\end{array}$ & $\begin{array}{c}22 \\
(59)\end{array}$ & $\begin{array}{c}21 \\
(57)\end{array}$ & 24 & 24 & 23 \\
\hline $\begin{array}{l}3 \text { Bank mortgages } \\
\text { marginal capital } \\
\text { requirement }\end{array}$ & $\mathrm{k}_{\mathrm{m}}$ & $\begin{array}{l}1.6 \text { percent to } 8 \\
\text { percent }\end{array}$ & 4 percent & $\begin{array}{c}41 \\
(19)\end{array}$ & $\begin{array}{l}55 \\
(33)\end{array}$ & $\begin{array}{c}70 \\
(48)\end{array}$ & $\begin{array}{c}22 \\
(38)\end{array}$ & $\begin{array}{c}22 \\
(67)\end{array}$ & $\begin{array}{l}22 \\
(95)\end{array}$ & 19 & 26 & 38 \\
\hline $\begin{array}{l}\text { 4. Annual mortgage } \\
\text { default rate }\end{array}$ & $\mathrm{q}$ & $\begin{array}{l}0 \text { to } 25 \text { basis } \\
\text { points }\end{array}$ & $\begin{array}{l}10 \text { basis } \\
\text { points }\end{array}$ & $\begin{array}{c}49 \\
(30)\end{array}$ & $\begin{array}{c}52 \\
(30)\end{array}$ & $\begin{array}{c}56 \\
(30)\end{array}$ & $\begin{array}{c}19 \\
(59)\end{array}$ & $\begin{array}{c}22 \\
(59)\end{array}$ & $\begin{array}{c}26 \\
(59)\end{array}$ & 24 & 24 & 24 \\
\hline $\begin{array}{l}\text { 5. Marginal } \\
\text { valuation cost }\end{array}$ & $\mathrm{t}$ & $\begin{array}{l}0 \text { to } 30 \text { basis } \\
\text { points }\end{array}$ & $\begin{array}{l}15 \text { basis } \\
\text { points }\end{array}$ & $\begin{array}{c}37 \\
(30)\end{array}$ & $\begin{array}{c}52 \\
(30)\end{array}$ & $\begin{array}{c}67 \\
(30)\end{array}$ & $\begin{array}{c}7 \\
(59)\end{array}$ & $\begin{array}{c}22 \\
(59)\end{array}$ & $\begin{array}{c}37 \\
(59)\end{array}$ & 24 & 24 & 24 \\
\hline $\begin{array}{l}\text { 6. Expected risk- } \\
\text { adjusted return to } \\
\text { capital }\end{array}$ & $r_{e}$ & $\begin{array}{l}10 \text { to } 20 \\
\text { percent }\end{array}$ & 15 percent & $\begin{array}{c}47 \\
(27)\end{array}$ & $\begin{array}{c}52 \\
(30)\end{array}$ & $\begin{array}{c}56 \\
(32)\end{array}$ & $\begin{array}{c}20 \\
(54)\end{array}$ & $\begin{array}{c}22 \\
(59)\end{array}$ & $\begin{array}{c}24 \\
(65)\end{array}$ & 17 & 22 & 27 \\
\hline $\begin{array}{l}\text { 7. Bank regulatory } \\
\text { marginal capital } \\
\text { requirement for } \\
\text { MBS portfolio }\end{array}$ & $\mathrm{k}_{\mathrm{mbs}}$ & $\begin{array}{l}1.6 \text { percent to } 4 \\
\text { percent }\end{array}$ & 2.5 percent & $\begin{array}{l}56 \\
(34)\end{array}$ & $\begin{array}{c}50 \\
(28)\end{array}$ & $\begin{array}{l}45 \\
(23)\end{array}$ & $\begin{array}{c}22 \\
(68)\end{array}$ & $\begin{array}{c}22 \\
(67)\end{array}$ & $\begin{array}{c}22 \\
(46)\end{array}$ & 26 & 23 & 20 \\
\hline
\end{tabular}




\begin{tabular}{|c|c|c|c|c|c|c|c|c|c|c|c|c|}
\hline $\begin{array}{l}\text { 8. Remaining } \\
\text { principal after } \\
\text { mortgage default }\end{array}$ & $r_{d}$ & $\begin{array}{l}60 \text { to } 100 \\
\text { percent }\end{array}$ & 80 percent & $\begin{array}{c}54 \\
(30)\end{array}$ & $\begin{array}{c}52 \\
(30)\end{array}$ & $\begin{array}{c}50 \\
(30)\end{array}$ & $\begin{array}{c}24 \\
(59)\end{array}$ & $\begin{array}{c}22 \\
(59)\end{array}$ & $\begin{array}{c}20 \\
(59)\end{array}$ & 24 & 24 & 24 \\
\hline $\begin{array}{l}\text { 9. Regulatory capital } \\
\text { requirement on } \\
\text { securitizer }\end{array}$ & $\mathrm{k}_{\mathrm{s}}$ & $\begin{array}{l}15 \text { to } 65 \text { basis } \\
\text { points }\end{array}$ & $\begin{array}{c}45 \text { basis } \\
\text { points }\end{array}$ & $\begin{array}{c}50 \\
(31)\end{array}$ & $\begin{array}{c}51 \\
(30)\end{array}$ & $\begin{array}{c}52 \\
(29)\end{array}$ & $\begin{array}{c}19 \\
(62)\end{array}$ & $\begin{array}{c}21 \\
(60)\end{array}$ & $\begin{array}{c}24 \\
(58)\end{array}$ & 25 & 24 & 23 \\
\hline $\begin{array}{l}\text { 10. Fixed cost } \\
\text { of mortgage } \\
\text { origination }\end{array}$ & $\mathrm{c}_{\mathrm{m}}$ & 0 to 2 percent & 1 percent & $\begin{array}{c}51 \\
(30)\end{array}$ & $\begin{array}{c}52 \\
(30)\end{array}$ & $\begin{array}{c}52 \\
(30)\end{array}$ & $\begin{array}{c}22 \\
(59)\end{array}$ & $\begin{array}{c}22 \\
(59)\end{array}$ & $\begin{array}{c}22 \\
(59)\end{array}$ & 24 & 24 & 24 \\
\hline
\end{tabular}




\begin{tabular}{|c|c|c|c|c|c|c|c|c|c|c|c|}
\hline \multicolumn{12}{|c|}{$\begin{array}{c}\text { Table 1B } \\
\text { Simulated Mortgage-MBS Spreads, Securitization Proportions and Profits for Nonconforming Market } \\
\text { Changes in these statistics in Response to Changes in Exogenous Parameters }\end{array}$} \\
\hline \multirow{3}{*}{$\begin{array}{c}\text { (1) } \\
\text { Parameter }\end{array}$} & \multirow{3}{*}{$\begin{array}{c}(2) \\
\text { Symbol }\end{array}$} & \multirow{3}{*}{$\begin{array}{l}\text { (3) } \\
\text { Parameter } \\
\text { Range } \\
\text { Used in } \\
\text { Simulation }\end{array}$} & \multirow{3}{*}{$\begin{array}{l}\text { (4) } \\
\text { Parameter } \\
\text { value } \\
\text { used } \\
\text { when } \\
\text { parameter } \\
\text { is fixed }\end{array}$} & \multicolumn{8}{|c|}{ Mean Values over Varying Parameter Values with Standard Deviations in parentheses } \\
\hline & & & & \multirow{2}{*}{$\begin{array}{l}\text { (5) } \\
\text { Nonconforming } \\
\text { Mortgage Rate } \\
\text { (Percent) }\end{array}$} & \multicolumn{2}{|c|}{ GSE Rates } & \multicolumn{5}{|c|}{ Nonconforming Mortgage Market } \\
\hline & & & & & $\begin{array}{l}(6) \\
\text { Monopolistic } \\
\text { Case } \\
\text { (Percent) }\end{array}$ & $\begin{array}{l}\text { (7) } \\
\text { Competitive } \\
\text { Case } \\
\text { (Percent) }\end{array}$ & $\begin{array}{l}(8) \\
\text { Rate - } \\
\text { Coupon } \\
\text { Spread } \\
\text { (Basis } \\
\text { Points) }\end{array}$ & $\begin{array}{l}\text { (9) } \\
\text { Proportion } \\
\text { Securitized } \\
\text { (Percent) }\end{array}$ & $\begin{array}{l}(10) \\
\text { Proportion } \\
\text { of Cash } \\
\text { Flow } \\
\text { Securitized } \\
\text { (Percent) }\end{array}$ & $\begin{array}{c}(11) \\
\text { Securitized } \\
\text { Capital } \\
\text { (Percent) }\end{array}$ & $\begin{array}{l}(12) \\
\text { Securitized Capital } \\
\text { and Default Value } \\
\text { of the Residual } \\
\text { Tranche } \\
\text { (Percent) }\end{array}$ \\
\hline $\begin{array}{l}\text { 1. Liquidity } \\
\text { value of } \\
\text { securitization }\end{array}$ & $\delta$ & $\begin{array}{c}0 \text { to } 100 \\
\text { basis } \\
\text { points }\end{array}$ & $\begin{array}{l}50 \text { basis } \\
\text { points }\end{array}$ & $\begin{array}{c}7.54 \\
(0.00)\end{array}$ & $\begin{array}{c}7.48 \\
(0.04)\end{array}$ & $\begin{array}{c}7.32 \\
(0.18)\end{array}$ & $\begin{array}{c}61 \\
(29.30)\end{array}$ & $\begin{array}{c}7 \\
(0.00)\end{array}$ & $\begin{array}{c}78.2 \\
(2.74)\end{array}$ & $\begin{array}{l}3.7 \\
(2.70)\end{array}$ & $\begin{array}{l}21.1 \\
(0.51)\end{array}$ \\
\hline $\begin{array}{l}\text { 2. Bank's cost } \\
\text { of deposits }\end{array}$ & $\mathrm{r}_{\mathrm{f}}$ & $\begin{array}{l}4 \text { percent } \\
\text { to } 8 \\
\text { percent }\end{array}$ & 6 percent & $\begin{array}{c}7.54 \\
(1.13)\end{array}$ & $\begin{array}{c}7.49 \\
(1.13)\end{array}$ & $\begin{array}{c}7.36 \\
(1.13)\end{array}$ & $\begin{array}{c}61 \\
(0.11)\end{array}$ & $\begin{array}{c}7 \\
(0.00)\end{array}$ & $\begin{array}{c}78.2 \\
(0.40)\end{array}$ & $\begin{array}{c}3.6 \\
(0.46)\end{array}$ & $\begin{array}{l}21.1 \\
(0.77)\end{array}$ \\
\hline $\begin{array}{l}3 \text { Bank } \\
\text { mortgages } \\
\text { marginal } \\
\text { capital } \\
\text { requirement }\end{array}$ & $\mathrm{k}_{\mathrm{m}}$ & $\begin{array}{l}1.6 \text { percent } \\
\text { to } 8 \\
\text { percent }\end{array}$ & 4 percent & $\begin{array}{c}7.61 \\
(0.17)\end{array}$ & $\begin{array}{l}7.55 \\
(0.14)\end{array}$ & $\begin{array}{c}7.37 \\
(0.06)\end{array}$ & $\begin{array}{c}61 \\
(0.02)\end{array}$ & $\begin{array}{c}7 \\
(0.00)\end{array}$ & $\begin{array}{l}78.1 \\
(0.13)\end{array}$ & $\begin{array}{c}3.6 \\
(0.01)\end{array}$ & $\begin{array}{l}21.1 \\
(0.10)\end{array}$ \\
\hline $\begin{array}{l}\text { 4. Annual } \\
\text { mortgage } \\
\text { default rate }\end{array}$ & $\mathrm{q}$ & $\begin{array}{l}0 \text { to } 25 \\
\text { basis } \\
\text { points }\end{array}$ & $\begin{array}{l}10 \text { basis } \\
\text { points }\end{array}$ & $\begin{array}{c}7.54 \\
(0.02)\end{array}$ & $\begin{array}{c}7.50 \\
(0.02)\end{array}$ & $\begin{array}{c}7.37 \\
(0.02)\end{array}$ & $\begin{array}{c}63 \\
(7.88)\end{array}$ & $\begin{array}{c}5 \\
(5.86)\end{array}$ & $\begin{array}{c}78.4 \\
(0.69)\end{array}$ & $\begin{array}{c}3.8 \\
(0.69)\end{array}$ & $\begin{array}{l}21.1 \\
(0.14)\end{array}$ \\
\hline $\begin{array}{l}\text { 5. Marginal } \\
\text { valuation cost }\end{array}$ & $\mathrm{t}$ & $\begin{array}{l}0 \text { to } 30 \\
\text { basis } \\
\text { points }\end{array}$ & $\begin{array}{l}15 \text { basis } \\
\text { points }\end{array}$ & $\begin{array}{c}7.53 \\
(0.08)\end{array}$ & $\begin{array}{c}7.49 \\
(0.09)\end{array}$ & $\begin{array}{c}7.36 \\
(0.09)\end{array}$ & $\begin{array}{c}61 \\
(0.01)\end{array}$ & $\begin{array}{c}7 \\
(8.79)\end{array}$ & $\begin{array}{c}78.2 \\
(1.03)\end{array}$ & $\begin{array}{c}3.6 \\
(1.03)\end{array}$ & $\begin{array}{l}21.0 \\
(0.21)\end{array}$ \\
\hline $\begin{array}{l}\text { 6. Expected } \\
\text { risk-adjusted } \\
\text { return to } \\
\text { capital }\end{array}$ & $\mathrm{r}_{\mathrm{e}}$ & $\begin{array}{l}10 \text { to } 20 \\
\text { percent }\end{array}$ & $\begin{array}{c}15 \\
\text { percent }\end{array}$ & $\begin{array}{c}7.54 \\
(0.12)\end{array}$ & $\begin{array}{c}7.49 \\
(0.11)\end{array}$ & $\begin{array}{c}7.36 \\
(0.10)\end{array}$ & $\begin{array}{c}61 \\
(0.01)\end{array}$ & $\begin{array}{c}7 \\
(0.00)\end{array}$ & $\begin{array}{c}78.7 \\
(1.65)\end{array}$ & $\begin{array}{c}4.1 \\
(1.68)\end{array}$ & $\begin{array}{c}21.2 \\
(0.36)\end{array}$ \\
\hline $\begin{array}{l}\text { 7. Bank } \\
\text { regulatory } \\
\text { marginal } \\
\text { capital } \\
\text { requirement } \\
\text { for MBS } \\
\text { portfolio }\end{array}$ & $\mathrm{k}_{\mathrm{mbs}}$ & $\begin{array}{l}1.6 \text { percent } \\
\text { to } 4 \\
\text { percent }\end{array}$ & $\begin{array}{c}2.5 \\
\text { percent }\end{array}$ & $\begin{array}{c}7.54 \\
(0.00)\end{array}$ & $\begin{array}{c}7.50 \\
(0.01)\end{array}$ & $\begin{array}{c}7.37 \\
(0.04)\end{array}$ & $\begin{array}{c}61 \\
(0.00)\end{array}$ & $\begin{array}{c}7 \\
(0.00)\end{array}$ & $\begin{array}{c}78.2 \\
(0.00)\end{array}$ & $\begin{array}{l}3.6 \\
(0.00)\end{array}$ & $\begin{array}{l}21.0 \\
(0.00)\end{array}$ \\
\hline
\end{tabular}




\begin{tabular}{|c|c|c|c|c|c|c|c|c|c|c|c|}
\hline $\begin{array}{l}\text { 8. Remaining } \\
\text { principal after } \\
\text { mortgage } \\
\text { default }\end{array}$ & $r_{d}$ & $\begin{array}{c}60 \text { to } 100 \\
\text { percent }\end{array}$ & $\begin{array}{c}80 \\
\text { percent }\end{array}$ & $\begin{array}{c}7.54 \\
(0.01)\end{array}$ & $\begin{array}{c}7.49 \\
(0.01)\end{array}$ & $\begin{array}{c}7.36 \\
(0.01)\end{array}$ & $\begin{array}{c}61 \\
(0.00)\end{array}$ & $\begin{array}{c}7 \\
(1.17)\end{array}$ & $\begin{array}{c}78.2 \\
(11.70)\end{array}$ & $\begin{array}{c}3.6 \\
(0.78)\end{array}$ & $\begin{array}{c}19.7 \\
(6.14)\end{array}$ \\
\hline $\begin{array}{l}\text { 9. Regulatory } \\
\text { capital } \\
\text { requirement } \\
\text { on securitizer }\end{array}$ & $\mathrm{k}_{\mathrm{s}}$ & $\begin{array}{c}15 \text { to } 65 \\
\text { basis } \\
\text { points }\end{array}$ & $\begin{array}{l}45 \text { basis } \\
\text { points }\end{array}$ & $\begin{array}{c}7.54 \\
(0.00)\end{array}$ & $\begin{array}{c}7.49 \\
(0.00)\end{array}$ & $\begin{array}{c}7.36 \\
(0.01)\end{array}$ & $\begin{array}{c}61 \\
(0.00)\end{array}$ & $\begin{array}{c}7 \\
(0.00)\end{array}$ & $\begin{array}{c}78.2 \\
(0.00)\end{array}$ & $\begin{array}{c}3.6 \\
(0.00)\end{array}$ & $\begin{array}{c}21.0 \\
(0.00)\end{array}$ \\
\hline $\begin{array}{l}\text { 10. Fixed cost } \\
\text { of mortgage } \\
\text { origination }\end{array}$ & $\mathrm{c}_{\mathrm{m}}$ & $\begin{array}{l}0 \text { to } 2 \\
\text { percent }\end{array}$ & 1 percent & $\begin{array}{c}7.54 \\
(0.59)\end{array}$ & $\begin{array}{c}7.49 \\
(0.59)\end{array}$ & $\begin{array}{c}7.36 \\
(0.59)\end{array}$ & $\begin{array}{c}61 \\
(0.06)\end{array}$ & $\begin{array}{c}7 \\
(0.00)\end{array}$ & $\begin{array}{c}78.2 \\
(0.45)\end{array}$ & $\begin{array}{c}3.6 \\
(0.03)\end{array}$ & $\begin{array}{r}21.0 \\
(0.34)\end{array}$ \\
\hline
\end{tabular}




\begin{tabular}{|c|c|c|c|c|c|c|c|c|c|}
\hline \multicolumn{10}{|c|}{$\begin{array}{l}\text { Table } 2 \\
\text { Simulated Comparative Statics } \\
\text { the Spread between GSE and Nonconforming Mortgage Rates } \\
\text { in Response to Changes in Exogenous Parameters }\end{array}$} \\
\hline \multirow[t]{2}{*}{$\begin{array}{c}\text { (1) } \\
\text { Parameter }\end{array}$} & \multirow[t]{2}{*}{$\begin{array}{c}(2) \\
\text { Symbol }\end{array}$} & \multirow[t]{2}{*}{$\begin{array}{c}(3) \\
\text { Parameter } \\
\text { Range } \\
\text { Used in } \\
\text { Simulatio } \\
\text { n }\end{array}$} & \multirow[t]{2}{*}{$\begin{array}{c}(4) \\
\text { Parameter } \\
\text { value used } \\
\text { when } \\
\text { parameter is } \\
\text { fixed }\end{array}$} & \multicolumn{2}{|c|}{$\begin{array}{l}\text { Mean and Standard Deviation } \\
\text { of Differences (with all } \\
\text { parameters the same) between } \\
\text { Nonconforming Mortgage } \\
\text { Rates and ... }\end{array}$} & \multicolumn{4}{|c|}{ Maximum Difference between Nonconforming Mortgage Rates and ... } \\
\hline & & & & $\begin{array}{l}\text { (5) } \\
\text { Monopolistic } \\
\text { GSE Rates } \\
\text { (Basis Points) }\end{array}$ & $\begin{array}{l}\text { (6) } \\
\text { Competitive } \\
\text { GSE Rates } \\
\text { (Basis Points) }\end{array}$ & $\begin{array}{c}\text { (7) } \\
\text { Monopolistic } \\
\text { GSE Rates at } \\
\text { Same } \\
\text { Parameters } \\
\text { (Basis Points) }\end{array}$ & $\begin{array}{c}(8) \\
\text { Competitive } \\
\text { GSE Rates at } \\
\text { Same } \\
\text { Parameters } \\
\text { (Basis Points) }\end{array}$ & $\begin{array}{c}(9) \\
\text { Monopolistic } \\
\text { GSE Rates for } \\
\text { Different } \\
\text { Parameters } \\
\text { within } \\
\text { Parameter } \\
\text { Range } \\
\text { (Basis Points) }\end{array}$ & $\begin{array}{c}(10) \\
\text { Competitive } \\
\text { GSE Rates for } \\
\text { Different } \\
\text { Parameters } \\
\text { within } \\
\text { Parameter } \\
\text { Range } \\
\text { (Basis Points) }\end{array}$ \\
\hline $\begin{array}{l}\text { 1. Liquidity } \\
\text { value of } \\
\text { securitizatio } \\
n\end{array}$ & $\delta$ & $\begin{array}{c}0 \text { to } 100 \\
\text { basis } \\
\text { points }\end{array}$ & $\begin{array}{c}50 \text { basis } \\
\text { points }\end{array}$ & $\begin{array}{c}5 \\
(4)\end{array}$ & $\begin{array}{c}22 \\
(18)\end{array}$ & 15 & 60 & 15 & 60 \\
\hline $\begin{array}{l}\text { 2. Bank's } \\
\text { cost of } \\
\text { deposits }\end{array}$ & $r_{f}$ & $\begin{array}{l}4 \text { percent } \\
\text { to } 8 \\
\text { percent }\end{array}$ & 6 percent & $\begin{array}{c}4 \\
(0)\end{array}$ & $\begin{array}{l}17 \\
(1)\end{array}$ & 4 & 19 & 389 & 403 \\
\hline $\begin{array}{l}3 \text { Bank } \\
\text { mortgages } \\
\text { marginal } \\
\text { capital } \\
\text { requirement }\end{array}$ & $\mathrm{k}_{\mathrm{m}}$ & $\begin{array}{c}1.6 \\
\text { percent to } \\
8 \text { percent }\end{array}$ & 4 percent & $\begin{array}{c}6 \\
(3)\end{array}$ & $\begin{array}{c}23 \\
(11)\end{array}$ & 11 & 45 & 59 & 65 \\
\hline $\begin{array}{l}\text { 4. Annual } \\
\text { mortgage } \\
\text { default rate }\end{array}$ & $\mathrm{q}$ & $\begin{array}{l}0 \text { to } 25 \\
\text { basis } \\
\text { points }\end{array}$ & $\begin{array}{l}10 \text { basis } \\
\text { points }\end{array}$ & $\begin{array}{c}4 \\
(0)\end{array}$ & $\begin{array}{l}17 \\
(0)\end{array}$ & 4 & 18 & 11 & 24 \\
\hline
\end{tabular}




\begin{tabular}{|c|c|c|c|c|c|c|c|c|c|}
\hline $\begin{array}{l}\text { 5. Marginal } \\
\text { valuation } \\
\text { cost }\end{array}$ & $\mathrm{t}$ & $\begin{array}{l}0 \text { to } 30 \\
\text { basis } \\
\text { points }\end{array}$ & $\begin{array}{l}15 \text { basis } \\
\text { points }\end{array}$ & $\begin{array}{c}4 \\
(1)\end{array}$ & $\begin{array}{l}17 \\
(1)\end{array}$ & 4 & 18 & 32 & 45 \\
\hline $\begin{array}{l}\text { 6. Expected } \\
\text { risk-adjusted } \\
\text { return to } \\
\text { capital }\end{array}$ & $r_{e}$ & $\begin{array}{l}10 \text { to } 20 \\
\text { percent }\end{array}$ & 15 percent & $\begin{array}{c}4 \\
(0)\end{array}$ & $\begin{array}{l}17 \\
(2)\end{array}$ & 5 & 21 & 43 & 54 \\
\hline $\begin{array}{l}\text { 7. Bank } \\
\text { regulatory } \\
\text { marginal } \\
\text { capital } \\
\text { requirement } \\
\text { for MBS } \\
\text { portfolio }\end{array}$ & $\mathrm{k}_{\mathrm{mbs}}$ & $\begin{array}{c}1.6 \\
\text { percent to } \\
4 \text { percent }\end{array}$ & 2.5 percent & $\begin{array}{c}4 \\
(1)\end{array}$ & $\begin{array}{l}16 \\
(4)\end{array}$ & 5 & 23 & 5 & 23 \\
\hline $\begin{array}{l}8 . \\
\text { Remaining } \\
\text { principal } \\
\text { after } \\
\text { mortgage } \\
\text { default }\end{array}$ & $r_{d}$ & $\begin{array}{l}60 \text { to } 100 \\
\text { percent }\end{array}$ & 80 percent & $\begin{array}{c}4 \\
(0)\end{array}$ & $\begin{array}{l}17 \\
(0)\end{array}$ & 4 & 18 & 8 & 21 \\
\hline $\begin{array}{l}9 . \\
\text { Regulatory } \\
\text { capital } \\
\text { requirement } \\
\text { on } \\
\text { securitizer } \\
\end{array}$ & $\mathrm{k}_{\mathrm{s}}$ & $\begin{array}{l}15 \text { to } 65 \\
\text { basis } \\
\text { points }\end{array}$ & $\begin{array}{l}45 \text { basis } \\
\text { points }\end{array}$ & $\begin{array}{c}4 \\
(0)\end{array}$ & $\begin{array}{l}18 \\
(1)\end{array}$ & 5 & 19 & 5 & 19 \\
\hline $\begin{array}{l}\text { 10. Fixed } \\
\text { cost } \\
\text { of mortgage } \\
\text { origination }\end{array}$ & $\mathrm{c}_{\mathrm{m}}$ & $\begin{array}{c}0 \text { to } 2 \\
\text { percent }\end{array}$ & 1 percent & $\begin{array}{c}4 \\
(0)\end{array}$ & $\begin{array}{l}17 \\
(0)\end{array}$ & 4 & 17 & 204 & 218 \\
\hline
\end{tabular}




\section{REFERENCES}

Ambrose, Brent W., Buttimer, Richard and Thibodeau, Thomas (2000), "A New Spin on the Jumbo/Conforming Loan Rate Differential” in mimeo, April 20, 2000.

Bruskin, Eric, Sanders, Anthony B., and Sykes, David (1999), “The Nonagency Mortgage Market: Background and Overview" in mimeo, March.

Canner, Glenn B., Passmore, Wayne, and Surette, Brian J. (1996), "Distribution of Credit Risk among Providers of Mortgages to Lower-Income and Minority Homebuyers," Federal Reserve Bulletin, (82), pp.1077-11-2.

Congressional Budget Office, (1996), Assessing the Public Costs and Benefits of Fannie Mae and Freddie Mac, Washington D.C.: Government Printing Office

Congressional Budget Office, (2001), Federal Subsidies and Housing GSEs, Washington D.C.: Government Printing Office

Cotterman, Robert F. and Pearce, James E. (1996), “The Effects of the Federal National Mortgage Association and the Federal Home Loan Mortgage Corporation on Conventional Fixed-Rate Mortgage Yields" in U.S. Department of Housing and Urban Development (Ed.), Studies on Privatizing Fannie Mae and Freddie Mac, U.S. Department of Housing and Urban Development, Washington D.C.: U.S. Department of Housing and Urban Development, 97-168.

Feldman, Ron (1999), "Estimating and Managing the Federal Subsidy of Fannie Mae and Freddie Mac: Is Either Task Possible?," Journal of Public Budgeting, Accounting and Financial Management, 11, Spring, pp. 81-116.

Glaeser, Edward L. and Kallal, Hedi D. (1997), "Thin Markets, Asymmetric Information, and Mortgage-Backed Securities," Journal of Financial Intermediation, 6-1,64-86.

Goodman, John L. Jr. and Passmore, S. Wayne (1992), "Market Power and the Pricing of Mortgage Securitization," Federal Reserve Board Finance and Economics Discussion Series, 187, 1-31.

Grossman, Sanford J. and Miller, Merton H. (1988), "Liquidity and Market Structure," The Journal of Finance, 43-3,617-633.

Hendershott, Patric H. and Shilling, James D. (1989), "The Impact of Agencies on Conventional Fixed-Rate Mortgage Yields.” The Journal of Real Estate Finance and Economics, 2, 101115 .

Hermalin, Benjamin E. and Jaffee, Dwight M. (1996), "The Privatization of Fannie Mae and Freddie Mac: Implications for Mortgage Industry Structure," in U.S. Department of Housing and Urban Development (Ed.), Studies on Privatizing Fannie Mae and Freddie Mac, U.S. 
Department of Housing and Urban Development, Washington D.C.: U.S. Department of Housing and Urban Development, 225-302.

Heuson, Andrea, Passmore, S. Wayne and Sparks, Roger (2000), “Credit Scoring and Mortgage Securitization: Do They Lower Mortgage Rates?," Finance and Economics Discussion Series (FEDS), 2000-44.

ICF Inc. (1990), Effects of the Conforming Loan Limit on Mortgage Markets, Final Report Prepared for the U.S. Department and Urban Development, Office of Policy Development and Research, Fairfax, VA: ICF Incorporated.

Inside Mortgage Finance Publications, Inc. (2000), The Mortgage Market Statistical Annual for 2000, Volume II: The Secondary Mortgage Market, P.O. Box 42387, Washington D.C. 20015

Mansukhani, Satish M., and Kramer, Bruce (2000), “Analyzing Loan-level Default Performance in the Jumbo MBS Sector,” Bear Stearns’ Residential Credit Research, Spring.

Pagano, Marco and Roell, Ailsa (1996), "Transparency and Liquidity: A Comparison of Auction and Dealer Markets with Informed Trading, The Journal of Finance, 51-2, 579-611.

Passmore, Wayne and Sparks, Roger (1996), "Putting the Squeeze on a Market for Lemons: Government-Sponsored Mortgage Securitization,” Journal of Real Estate Finance and Economics, 96-13, 27-43.

Passmore, Wayne and Sparks, Roger (2000), "Automated Underwriting and the Profitability of Mortgage Securitization,” Real Estate Economics, (28) Summer, Number 2.

U.S. Department of Treasury (1996), Government Sponsorship of the Federal National Mortgage Association and the Federal Home Loan Mortgage Corporation, Washington D.C.: Government Printing Office.

U.S. General Accounting Office (1996), Housing Enterprises: Potential Impacts of Severing Government Sponsorship, Washington D.C.: Government Printing Office. 